\title{
Nâzım Hikmet'in Edebiyat Alanındaki Konumuna ve Eserlerinin Çeviri Yoluyla Dolaşımına Kısıtların Olumlu Etkileri ${ }^{1}$
}

\author{
The Positive Effects of Constraints on Nâzım Hikmet's Position in the Field of Literature \\ and the Circulation of His Works Through Translation
}

Araştırma / Research

\section{Linda MIĞDIS ŞEKER*, Z. Emine BOGENÇ DEMIREL** \\ * Doktora Öğrencisi, Yıldız Teknik Üniversitesi, Sosyal Bilimler Enstitüsü, Diller ve Kültürlerarası Çeviribilim Doktora Programı, linda_migdis@hotmail.com, ORCID-ID: orcid.org/0000-0003-0228-7773 \\ ** Prof. Dr., Yıldız Teknik Üniversitesi, Fen Edebiyat Fakültesi, Batı Dilleri ve Edebiyatları Bölümü, emine.bodem@gmail.com, ORCID-ID: orcid.org/0000-0001-6995-2198}

\section{ÖZET}

Nâzım Hikmet, şiir dili, temaların çeşitliliği ve evrenselliği, dünya insanı bakış açısı ile Türkçe şiirin dünyadaki en önemli temsilcilerinden biridir. Nâzım Hikmet'in dünyada oluşan imgesinin, şairin kültürel ve simgesel sermayelerinin, alanda karşılaştığı kısıtların bir sonucu olduğu düşünülebilir. Gisèle Sapiro, çeviri yoluyla yazınsal metinlerin uluslararası dolaşımı üzerine yaptığı çalışmalarda, kısıtların bazı koşullarda eyleyicilerin uluslararası tanınırlığını tetikleyebileceğini vurgular. Nâzım'ın da alanda karşılaştığı kısıtlar evrensel bilinirliğini bir anlamda tetiklemiştir. Nâzım Hikmet hem şiirinin gücü hem de kişisel yaşantısında karşılaştığı zorluklar neticesinde, toplumsal uzamda ideolojik anlamda aynı paralelde hareket ettiği eyleyicilerin ilgisini çekmiştir. Böylece, yasaklı olduğu için kendi memleketinde gerçekleştiremediği yazınsal alandaki dolaşımı, çeviriler ve özgürlüğü için yapılan kampanyalar sayesinde uluslararası yazınsal alanda gerçekleştirmiştir. Öyleyse, edebiyat alanında karşılaştığı politik, kültürel ve ekonomik kısıtların, iktidar sahiplerinin tahakkümünün ve maruz kaldığı simgesel şiddetin Nâzım’ın uluslararası alana taşınmasına katkıda

\footnotetext{
${ }^{1}$ Bu çalışma, Yıldız Teknik Üniversitesi, Sosyal Bilimler Enstitüsü, Diller ve Kültürlerarası Çeviribilim Doktora programında, Prof. Dr. Z. Emine Bogenç Demirel danışmanlığında yürütülmekte olan doktora tezinden üretilmiştir.
} 
bulunduğu düşünülebilir. Bu çalışmada, Pierre Bourdieu sosyolojisinde açıklanan alan, habitus, ekonomik sermaye, kültürel sermaye, toplumsal sermaye, simgesel sermaye, konum alma/konumlanma, ilişkisellik kavramları ve Sapiro'nun açıkladığı kısıt kavramı çerçevesinde, Nâzım Hikmet'in hangi koşullarda evrensel bir değere dönüştüğü, şiirlerinin hangi yıllarda, hangi dillere ve kimler tarafından çevrildiği dikkate alınarak görünür kılınmaya çalışılmıştır ve şairin hapishane hayatının kısıtlarına karşın sürdürdüğü usta-çırak ilişkileri incelenmiştir. Çalışmanın amacı ise yıllarını oldukça zorlu koşullarda kapalı mekânda geçirmesinin, Nâzım Hikmet'in evrensel boyuttaki tanınırlığına, üretkenliğine, insan ilişkilerine, yapılanırken yapılandırmasına nasıl katkı sağladığını, yani kısıtların şairin yaşamındaki olumlu etkilerini, şairin edebî, yaratıcı ve öğretici habitusu, yazınsal alandaki konumu, şiiri, yaşantısı ve tüm bunların ilişkiselliği doğrultusunda tartışmaktır.

Anahtar Sözcükler: Nâzım Hikmet, kısıtlar, çeviri sosyolojisi, sermaye, dolaşım

\begin{abstract}
Nâzım Hikmet is one of the most important representatives of Turkish poetry in the world by means of the language of his poetry, diversity and universality of the themes and his "man of the world" perspective. It can be thought that the image of Nâzım Hikmet in the world is the result of his cultural and symbolic capitals and the constraints he faced in the field. In the studies on the international circulation of literary texts by means of translation, Gisèle Sapiro emphasises that constraints may trigger international recognition of actors in some circumstances. In a sense, the constraints faced by Nâzım in the field triggered his universal recognition. As a result of both the power of his poetry and the difficulties he faced in his personal life, Nâzım Hikmet had attracted the attention of the actors with whom he had been moving ideologically parallel in social space. Thus, owing to translation of his poems and the campaigns held for his freedom, he fulfilled the circulation in the international literary field, which he could not actualise in the literary field of his own country because he was banned. Therefore, it may be considered that the political, cultural and economic constraints Nâzım had faced in the field of literature, the domination of the rulers and the symbolic violence that he had been exposed to contributed to his transfer to the international arena. In this study, within the framework of the concepts of field, habitus, economic capital, cultural capital, social capital, symbolic capital, position taking/positioning, relationality explained by Pierre Bourdieu in terms of his sociology and the notion of the constraint clarified by Sapiro, it has been tried to be brought into view in which circumstances Nâzım Hikmet had turned into a universal value by considering when his poems have been translated into which languages by whom and the master-apprentice relationships maintained by the poet despite the constraints of life in prison have been examined. The aim of the study is to discuss how spending his years in a confined space under hard conditions contributed to Nâzım Hikmet's universal recognition, productivity, human relations, being structured while structuring, in other words, the positive effects of constraints in the poet's life, in accordance with the poet's literary, creative and instructive habitus, his position in the literary field, his poetry, his life and the relationality of all above.
\end{abstract}

Keywords: Nâzım Hikmet, constraints, the sociology of translation, capital, circulation 
İçerde bir tarafınla yapayalnız kalabilirsin kuyunun dibindeki taş gibi fakat öbür tarafın öylesine karışmalı ki dünyanın kalabalığına sen ürpermelisin içerde dışarda kırk günlük yerde yaprak kıpırdasa.

$[\ldots]^{\prime \prime 2}$

Nâzım Hikmet

\section{Giriş}

Türkçe şiirin dünyadaki en büyük ve en önemli temsilcilerinden biri olan Nâzım Hikmet, çocukluk çağından başlayıp ölene kadar yaşantısı ve sanatı yoluyla hayatın tam içinde kalmayı başarmıştı; tüm yaşadıklarını, hissettiklerini, düşüncelerini, ideolojisini, kişiliğini olanca açıklığı ile şiirlerinde okuruna aktarmıştır; üstelik hapishanede geçirdiği ya da yasaklı olduğu dönemlerde dahi yazmaktan, şiirleriyle kendini ifade etmekten vazgeçmemiştir. Nicelik bakımından okuruna büyük bir külliyat sunan şair, nitelik olarak da çok yönlü, çok katmanlı, sürekli değişen, gelişen ve olgunlaşan bir şiir anlayışıyla eserler verir; bu eserler çeviri yoluyla birçok farklı ülkenin okuruna ulaşmıştır ve böylece şairin şiirleri dünya edebiyatındaki yerini almıştır.

Nâzım Hikmet, gerek kullandığı yalın, kendine özgü dili, gerek temalarındaki çeşitlilik ve dünya insanı bakış açısıyla Türkçe şiirin dünyada da dikkat çekmesini sağlamıştır. Bu bağlamda, kendini bir dünya insanı olarak konumlandıran şair, eserlerini evrensel bir edebiyat anlayışı doğrultusunda kaleme almıştır ve bu eserler italyanca, Yunanca, İngilizce, Rusça, Fransızca, İspanyolca, Almanca, Japonca, Urduca gibi birçok dile çevrilmiştir. Şairin ideolojisi, her şeye rağmen korumayı başardığı dik duruşu, tahakküme boyun eğmemesi ve çoğunlukla sergilediği olumlu yaklaşımı da üzerinde durulması gereken noktalardır; çünkü savunduğu ideoloji sayesinde dünyada aynı görüşü paylaşan sanatçıların ve entelektüellerin dikkatini çekmiştir, kendi ülkesinde yasaklı olduğu ve hapishanede geçirdiği dönemde dahi şiirleri serbest kalması için dünya çapında gerçekleştirilen kampanyalar yardımıyla ve çeviri yoluyla diğer dillerde okunmaya devam etmiştir. Öte yandan, yaratıcı ve öğretici habitusunun bir sonucu olarak Nâzım'ın her zaman canlı tuttuğu insan sevgisi ve yapıcılı̆ıı, kapalı alanda da üretken ve aynı zamanda yardımsever olmasına önayak olmuştur; hapishane koşullarında kurduğu usta-çırak ilişkileri de bunun bir göstergesidir.

Bu düşüncelerden hareketle, bu çalışmada Nâzım Hikmet'in hangi koşullarda evrensel bir değere dönüştüğü, ülkesinde yasaklı olduğu dönemde çeşitli dillere yapılan çeviriler yoluyla yazın alanında nasıl dolaşımda tutulduğu ve hapishanenin kısıtlarına karşın sürdürdüğü usta-çırak ilişkileri, çeviri sosyolojisi çerçevesinde incelenmiştir. Çalışmanın amacı, Nâzım Hikmet'in uzun yıllarını hapishanede oldukça kısıtlı imkânlarla, zorlu koşullarda geçirmesinin onun yaratııılı̆̆ına, kurduğu ilişkilere, öğreticiliğine, alanda bir yandan yapılanırken bir yandan da başkalarını yapılandırmasına ve evrensel boyuttaki

${ }^{2}$ Nâzım Hikmet'in Mayıs 1949'da kaleme aldığı “Hapiste Yatacak Olana Bazı Öğütler" adlı şiirinden bir kesit. Nâzım Hikmet, Bütün Şiirleri, 2009. 
tanınırlığına nasıl katkı sağladığını, kısıt kavramı vasıtasıyla şairin yaşamı, şiiri ve alanda aldığı konumun ilişkiselliği üzerinden tartışmaktır.

\section{Yöntemsel Yaklaşım}

Nâzım Hikmet'in yaşamında ve edebiyat alanında karşılaştığı kısıtların olumlu etkilerini değerlendirmek için çeviri sosyolojisi çerçevesinde Pierre Bourdieu'nün sosyolojisinin alan, habitus, sermaye (ekonomik, kültürel, simgesel, toplumsal), çıkar (illusio) ${ }^{3}$, ilişkisellik gibi kavramlarından ve Bourdieu'nün doktora tez danışmanlığını yaptığı öğrencisi Gisèle Sapiro'nun açıkladığı kısıt kavramından yararlanılacaktır.

Bourdieu sosyolojisinin temel kavramlarından biri olan alan, toplumdaki tüm eyleyicilerin konumlandığı/konum aldığı, her eyleyicinin kendi çıkarları ve stratejileri doğrultusunda mücadele ettiği yapı olarak tanımlanabilir. Alan, oyun kavramıyla açıklanırsa:

Bir oyunda; oyuncular, onların yatırımları, çıkar amaçları, stratejileri, açıkça ifade edilmeyen kurallar (doksa), herkesin sahip olduğu kartlar vardır. Oyuncular, toplumdaki eyleyiciler, yani genel anlamda toplumdur. [...] Alan bu oyunun oynandığı yerdir ve kişilerin sermayesine göre alandaki güç ağırlığı, kazanma/kaybetme şansı farklılık gösterir. (Özsöz, 2010, ss. 3-4)

Buna göre alandaki tüm eyleyicilerin, belli çıkarları söz konusudur ve her oyuncu farklı sermayelere sahiptir. Bourdieu, sermaye kavramını, dört başlıkta açıklar; bunlardan ilki Karl Marx'ın sermaye kavramıyla ortaya koyduğu gibi maddî kaynakları temsil eden ekonomik sermayedir. Kültürel sermaye, eğitimi, becerileri, yetkileri kapsarken; toplumda oluşan ilişkiler bütünü olarak açıklanan sermaye türü toplumsal sermayedir. Bu üç sermaye çeşidinin içinde barındırdığı ve bir şekilde dönüştüğü sermaye türü ise eyleyicinin prestijini ve toplumsal statüyü temsil eden simgesel sermayedir. Bourdieu bir alanın oluşumunu, özerkliğin kazanılması, yapının ortaya çıkması ve simgesel sermayenin oluşumu şeklinde üç aşamalı olarak ele alır:

Özerkliğin kazanılması, bir anlamda içinde bulunulan alana direniş göstermektir. Bu direniş sayesinde iki cephesi bulunan bir çatışma doğar ve kendi alanına sahip olan (örneğin yazınsal) alan, kendi sermayesini oluşturarak, oluşumunu tamamlar. $\mathrm{Bu}$ süreç, habitusun oluşması ve bu sayede alanın kendisini sürekli yeniden üretmesiyle devam eder. (Özsöz, 2007, s. 17)

Eyleyici, mücadeleli alandaki stratejilerini sahip olduğu sermayelerine, çıkarlarına ve tüm alan ile ilişkisellik içinde gelişen habitusuna göre biçimlendirir. Bourdieu ve Loïc Wacquant'ın Düşünümsel Bir Antropoloji Için Cevaplar (2012) adlı ortak yapıtında alan - habitus ilişkisi şöyle açıklanır:

İnsanın varoluşu ya da bedenleşmiş toplumsallık olarak habitus, dünyayı belli bir dünya olarak var eden şeydir. Pascal'ın dediği gibi, 'dünya beni içeriyor, ama ben onu anlıyorum' [...] Kendimi ifade etmek için Pascal'ın sözü üzerinde daha uzun durabilirim: Dünya beni içeriyor, ama tam da beni içerdiği için onu anlıyorum;

\footnotetext{
${ }^{3}$ Bu kavram makale boyunca 'çıkar' olarak kullanılacaktır.
} 
beni ürettiği için, ona ilişkin kullandığım kategorileri ürettiği için, bana apaçık görünüyor. (s. 118)

Öyleyse eyleyici alanda konum alırken beğenileri ve algısı devreye girer; bunun sonucu olarak alandaki konumu, sermayesi doğrultusunda ve habitusuna göre belirlenir. "Habitus ile alan arasındaki ilişki, öncelikle bir koşullanma ilişkisidir: Alan, habitusu yapılandırır. Habitus, bir alanın ya da kesişen bir dizi alanın [...] içkin zorunluluğunun somutlaşmasının ürünüdür" (s. 118). Bourdieu'ye göre habitus, "bedenleşmiş toplumsallık" (s. 118) ve "toplumsallaşmış bir öznellik"tir (s. 116). Habitus, "[t]arihin ürünü olduğundan, sürekli olarak yeni deneyimlerle karşı karşıya gelen ve durmaksızın onlardan etkilenen, açık bir yatkınlıklar sistemi"dir; "bir kader değil; sürekli dönüşen, yapılanan bir örüntüler sistemi"dir (s. 125).

Bourdieu, Pratik Nedenler (2005) adlı eserinde, "yazınsal mikrokozmos"tan söz eder: "Kültür yapılarının içinde üretildiği toplumsal mikrokozmos, yani yazınsal alan, sanatsal alan, bilimsel alan vb., konumlar arasındaki - örneğin kutsanan sanatçıla lanetlenen sanatçının konumları - bir nesnel bağıntılar alanıdır" (s. 62). Bu alanda, "üretici stratejileri", "savundukları sanat biçimi", "kurdukları ittifaklar", "oluşturdukları ekoller" mücadele ve çıkarlar doğrultusunda belirlenir. Dolayısıyla, yazınsal alanda ilişkisellik içinde süregelen bir mücadeleli işleyiş söz konusudur; Bourdieu, Seçilmiş Metinler (2014) adlı eserin "Entelektüel Alan: Kendine Özgü Bir Dünya" başlıklı bölümünde, "[...] edebiyat alanının bir güç ilişkileri alanı olmakla eş zamanlı olarak var olan güç ilişkilerini muhafaza etmeyi veya dönüştürmeyi hedefleyen bir mücadele alanı olduğunu" belirtir (ss. 216-217). Alanda ekonomik sermayeyi elinde bulunduran iktidarın tahakkümü ve bunun karşısına konumlanmış, tahakküme boyun eğmemek için direnen, kültürel alanda üretim yapan eyleyiciler söz konusudur. İktidarın karşısında duran ve ürünlerini bu doğrultuda alana sunan eyleyiciler, iktidarın çıkarlarına uymayan eylemlerinin sonucunda zaman zaman çeşitli kısıtlarla karşı karşıya kalırlar.

Kısıt kavramı, Türk Dil Kurumu’nun Güncel Türkçe Sözlüğünde “kişinin yurttaşlık haklarını kullanma yetkisinin yargı kuruluşları tarafından kaldırılması" ve "bunama, mahkûm olma vb. nedenlerden dolayı kanunun, bir kimsenin malını, parasını istediği gibi kullanmasına ve harcamasına engel olması, kısıtlılık, kısıtlama, hacir" şeklinde tanımlanmıştır. ${ }^{4}$ Aynı kavram, hukuk sözlüğünde ise 'hacir' sözcüğü üzerinden şöyle tanımlanmıştır: "Bir şahsın medeni haklarını kullanma salahiyetinin mahkeme tarafından kaldırılması". ${ }^{5}$

Bourdieu sosyolojisinden yola çıkan Sapiro (2008) ise kültürel üretim alanındaki ürünlerin dolaşımı esnasında eyleyicilerin karşı karşıya kaldığı kısıtları, "Normes de traduction et contraintes sociales" [Çeviri Normları ve Toplumsal Kısıtlar] başlıklı makalesinde çevirmenler üzerinden açıklar (ss. 199-208) Sapiro'ya göre, metnin sosyal konumu ile metni aktaranın sosyal konumu değişken ve ilişkiseldir; "kültürel transfer", yani sembolik ürünlerin taşınması ya da dolaşımı sırasında politik, ekonomik ve kültürel kısıtlar söz konusudur: Politik kısıtlar "iki ülke arasındaki siyasî ilişkilerin niteliğiyle

\footnotetext{
${ }^{4}$ https://sozluk.gov.tr

${ }^{5}$ https://sozluk.adalet.gov.tr/hacir
} 
ilgilenirken, ekonomik kısıtlar pazar mantığı ile düzenlenen kültürel aktarımların kısa vadede ekonomik kazanç sağlamak için üretilmesi ile ilgilidir. Kültürel kısıtlar ise kaynak ve erek kültürü barındıran ülkelerdeki kültürel üretim alanlarının yapısı ile ilişkilidir" (Bogenç Demirel, 2014, s. 412). Politik kısıtların egemen olduğu bir yerde, politik alan ekonomik alandan üstündür ve bunun sonucunda da kültürel ürünlerin üretimi ve dolaşımı iktidar tarafından düzenlenir. Bu noktada çeviri de bir ideolojik araç hâline gelir.

Sapiro, "How Do Literary Works Cross Borders (or Not)? A Sociological Approach to World Literature" (2016) başlıklı makalesinde ise kısıtları birbiriyle ilişkili olduğunu söylediği dört kategoride değerlendirir: politik, ekonomik, kültürel ve sosyal faktörler. Sapiro'ya göre, “[p]olitik ve daha çok ideolojik faktörler yazınsal metinlerin dolaşımını tetikleyebilir ya da zorlaştırabilir. Çeviri politik ya da ideolojik amaçlara hizmet edebilir; bir öğretiyi ya da bir dünya görüşünü yaymak için bir yol olabilir"6 $(2016$, s. 83). Bu noktada, yazar-çevirmen habituslarının ilişkiselliğinden söz edilebilir; çevirmen, çevirisini yaptığı eserin yazarının simgesel sermayesinden yararlanır ve yazarı başka bir kültüre taşıyarak, aynı zamanda onun da simgesel sermayesine katkıda bulunur. Sapiro'ya göre ekonomik faktörler de eserlerin dolaşımında oldukça etkilidir. Yayıncılık pazarının "kültürel (dilbilimsel) ve politik" sınırlara göre yapılandığını söyleyen Sapiro (2016, s. 85) ülkeler arasındaki politik, ekonomik ve kültürel güç ilişkilerinin eserlerin sınırları aşmasında etkili olduğunu belirtir. Otoriter rejimlerde, toplumu homojenleştiren temel aracın kısıtlar olduğu düşünülebilir (s. 93).

Peki tüm bu kavramlar ışığında düşünüldüğünde, kısıtlar kültürel ürünlerin aktarımını ve dolaşımını ya da iktidarın tahakkümüne maruz kalan şairin/yazarın ulusal ve uluslararası tanınırlığını olumlu anlamda nasıl etkiler, Sapiro'nun da belirttiği gibi politik kısıtlar ya da ideolojik yakınlık, yazınsal metinlerin uluslararası dolaşımını nasıl tetikleyebilir? Nâzım Hikmet'in hayatı, Türkçe şiirdeki konumu ve dünyadaki algılanışı bu kavramlar ışığında incelenecektir; ideolojisi sebebiyle karşı karşıya kaldığı kısıtların, politik baskının ve simgesel şiddetin, onun ulusal ve uluslararası tanınırlığına nasıl katkı sağladığı ve kapalı mekânda kaldığı uzun yıllar boyunca sürdürdüğü usta-çırak ilişkileri vasıtasıyla ayakta tuttuğu kültürel ve simgesel sermaye aktarımına kısıtların nasıl etki ettiği yukarıda açıklanan Bourdieu sosyolojisi kavramları çerçevesinde tartışılacaktır.

\section{Nâzım Hikmet'in Şair Habitusuna ve Edebiyat Alanındaki Konumuna Kısıtların Olumlu Etkisi}

\subsection{Nâzım Hikmet'in Hayatına Kısa Bir Bakış ve Nâzım Hikmet'in Türkçe Şiirdeki Konumu}

Selânik'te, (resmî kaynaklara göre) 15 Ocak 1902 tarihinde (aslında 20 Kasım 1901'de) dünyaya gelen Nâzım Hikmet, aristokrat bir aileye mensuptur; annesi ressam Celile Hanım, babası hariciye memuru Hikmet Nâzım Bey'dir; ancak buna rağmen yaşamı çocukluğundan itibaren pek iyi koşullarda geçmez. Çocuk yaşta, anne ve babasının boşanması, babasının erken vefatı ve ailece yaşadıkları maddî zorluklar şairin eğitim

${ }^{6}$ Çeviri tarafımızca yapılmıştır. 
hayatını da etkilemiştir. Galatasaray Sultanisi'nde başladığı lise öğrenimini, parasal güçlükler sebebiyle Nişantaşı Sultanisi'nde tamamlamak zorunda kalmıştır.

Nâzım Hikmet, 1913 yılında ilk şiirlerini dönemin şiir anlayışı doğrultusunda ölçü ve uyak gözeterek kaleme almaya başlar: "Feryad-ı Vatan" (1913), "Servilikler" (1916), "Hâlâ Servilerde Ağlıyorlar mı?” (1918), “Herkes Gibi” (1920), "Yol Türküsü" (1920) gibi şiirleri eski biçimli şiirlerinden bazılarıdır. 1915 yılında Heybeliada Bahriye Mektebi'ne başlayan Nâzım Hikmet'in ilk kez bir şiiri ("Hâlâ Servilerde Ağlıyorlar mı?"), Mehmed Nâzım imzasıyla Yeni Mecmua'da 3 Ekim 1918 tarihinde yayımlanır. 1919 yılında, Bahriye Mektebi'ni bitirip stajyer bahriye subayı olarak atanır, fakat 1920 yılında sağlık problemleri sebebiyle askeriyeden uzaklaştırılır.

Arkadaşı Vâlâ Nurettin ile bir süre Bolu'da öğretmenlik yaparak millî mücadeleye katkı sağlamayı hedefleseler de burada çok uzun süre barınamazlar ve Eylül 1921'de Batum üzerinden Moskova'ya giderler. Burada Doğu Emekçiler Komünist Üniversitesi'nde (KUTV) eğitim gördüğü sırada katıldığı bir toplantıda Mayakovski'yi tanıyan Nâzım Hikmet, onun basamaklı, inişli - çıkışlı, serbest nazımla yazılmış şiirinden ve şahsından nasıl etkilendiğini Bedri Rahmi Eyüboğlu'nun arşivindeki Fransızca söyleşide şöyle dile getirir: "[...] İçerideki herkes bağırıyordu. Ama bir bas ses bütün bu haykırışların üstüne çıkıyordu, bir çan sesi gibi hepsini bastırıyordu. O çan sesini işitmekle kalmadım, çan kulesini de gördüm, deyim yerindeyse. Dev gibi bir çan kulesi" (Nâzım Hikmet, 2011, ss. 96-97). 1922 yılında, 20 yaşında genç bir şairdir ve Mayakovski'nin okuduğu şiirden o dönemde henüz Ruşça bilmemesine rağmen öylesine etkilenir ki "kafama darbeler iniyor gibi oldu, enerji doluydu, çok dinamikti" der ve Mayakovski'nin merdiven çıkar gibi yazdığını dile getirir. Konstrüktivizmin etkisiyle klasik Türkçe şiir anlayışını bir kenara bırakıp yeni bir dil ve biçimle şiirler yazmaya başlar.

Değil birkaç

değil beş on

otuz milyon

aç

bizim!

\section{Onlar}

bizim!

Biz

onların!

Dalgalar

denizin!

Deniz

dalgaların!

Değil birkaç değil beş on

30.000.000 


\title{
30.000.000!
}

\author{
Açlar dizilmiş açlar! \\ Ne erkek, ne kadın, ne oğlan, ne kız \\ sıska cılız
}

eğri büğrü dallarıyla

eğri büğrü ağaçlar!

Ne erkek, ne kadın, ne oğlan, ne kız

\section{[...] (Nâzım Hikmet, 2009)}

açlar dizilmiş açlar!

Yukarıdaki dizelerle başlayan "Açların Gözbebekleri” şiiri 1922 yılında yayımlanır; serbest nazımla kaleme alınmış ilk Türkçe şiirdir ve bu anlamda bir devrim niteliği taşır. Ölçü, uyak olmaksızın, vurguları belirtmek için kalınlı inceli, büyüklü küçüklü puntolarla kaleme alınan bu etkileyici şiir, tema bağlamında da yenilikçidir. Şiirde, Nâzım’ın Moskova'ya giderken yolda gördüğü sefalet içindeki insanların durumunu, şairin komünist bakış açısının bir yansıması, yeniden yazımı olarak görürüz.

Nâzım Hikmet, 1924'te yurda dönüp Türkiye Komünist Partisi'ne üye olur, fakat tutuklamalar başlayınca 1925'te yeniden Moskova'ya gider. 1928 yılında tekrar yurda dönse de kısa tutukluluklardan kurtulamaz. 1929'da ise 835 Satır adlı kitabı yayınlanır. 1933 ve 1937 ' de farklı sebeplerle tutuklamalar söz konusu olur ve nihayetinde 1938 ' de orduyu isyana teşvik suçlamasıyla, önceki hükümlerle birlikte, toplam 28 yıl 4 ay cezaya mahkûm edilir; bir süre Ankara ve Çankırı hapishanelerinde kaldıktan sonra Bursa Hapishanesi'ne gönderilir ve 1950'de çıkan Genel Af Yasası kapsamında serbest bırakılıncaya kadar, on yıl boyunca burada kalır. Serbest kalması onu özgür kılmaz, içine düştüğü tehlikeden kaçmak için 1951'de Refik Erduran ile yaptıkları bir plan sonucunda memleketinden ebediyen ayrılır; önce Erduran'ın kullandığı sürat motoruyla Karadeniz'e açılırlar, motorla devam etmenin sorun yaratacağını anladıklarında ise açık denizde karşılarına çıkan ve uzun uğraşlar sonucunda onu almayı kabul eden Romanya şilebi vasıtasıyla Bükreş üzerinden Moskova'ya geçer. Ömrünün geri kalanını da dünyanın dört bir yanına çeşitli seyahatler gerçekleştirmek suretiyle Moskova' da geçirir. 3 Haziran 1963 tarihinde, daha önce de birçok kez onu yatağa düşüren ve şiirlerine çokça konu ettiği onulmaz kalp rahatsızlığı sebebiyle Moskova'daki evinde yaşamını yitirir. Görece kısa yaşamına çokça aşk, evlilik ve evlat sığdırır, sevdalarını da şiirlerinde okuruna açık bir dille ve tüm duygu yoğunluğuyla anlatır.

Modern Türkçe şiirin en büyük şairi Nâzım Hikmet, şiire getirdiği yeni dil ve yeni anlayışla, şiirdeki en büyük devrimcidir. Cesurca yazdığı yeni biçimli şiirleri, eski anlayışı gözeten aydınlar tarafından önceleri eleştirilse de sonrasında övgü dolu eleştirilere de nail olmuştur. Nedim Gürsel'in Dünya Şairi Nâzım Hikmet adlı kitabının ön sözünde belirttiği gibi: "Nâzım, yenilikçi atılımıyla geleneğe dönüş çizgilerinin kesiştiği yerde kendi yolunu bulmuş, kişiliğini bu kesişme noktasından yola çıkarak geliştirebilmişti" (2008, s. 37). Şiirindeki özgün ses öyle güçlü duyulur ki Ahmet Haşim, Nâzım Hikmet şiirini bir orkestra olarak nitelendirir: "Bu vezin bildiğimiz vezinlerden değil, bu lisan şiirin bizde 
bugüne kadar kullandığı lisana benzemiyor. [...] Nâzım Hikmet Bey bu tarzı anlamış, Türkçeleştirmiş, bu iklimin toprağında tutturabilmiş büyük bir yeni şairimizdir [...]" (Fuat, 2006, ss. 16-17). Öyleyse, Nâzım Hikmet, özümsediği bu yeni şiiri kendi dilinde ve kültüründe yeniden yazmıştır; yeni ve yerli bir şiir yaratmıştır. "Nâzım yazınsallığın metinlerarasılıktan geçtiğinin farkındadır. Geleneğin hem doğu hem batı şiiri geleneği bağlamında yeniden üretilmesi ile temellendiğini kavrar. [...] Şiirin arkeolojisindeki geleneksel katmanları gizleme gereği duymadığını belli eder, kaynaklarını kendisi gösterir okuruna (Yavuz, 2005, s. 196)" (bkz. Dicle, 2019, s. 118).

Şiir alanındaki başarısı, gücü, yaratıcılığının sınırsızlığı, kuşkusuz çok az rastlanır bir durumdur; fakat ne yazık ki şaire yaşatılan uzun tutukluluk süreci ve kitaplarının yasaklı olması sebebiyle, Nâzım Hikmet şiirini, çok sevdiği memleketinin insanları çok geç tanırlar. Nâzım Hikmet'in alanda aldığı konumu, ideolojisi onu kapalı mekâna hapsederken, şiirlerini de halkından ayrı düşürür; ancak şair her koşulda, kısıtlara rağmen üretmeye devam eder ve bunu 1947'de kaleme aldığı "Yatar Bursa Kalesinde" şiirinde dile getirir:

\author{
Sevdalınız bir komünisttir, \\ on yıldan beri hapistir, \\ yatar Bursa kalesinde. \\ Hapis ammâ, zincirini kırmış yatar, \\ en âlâ mertebeye ermiş yatar, \\ yatar Bursa kalesinde. \\ Memleket toprağındadır kökü, \\ Bedreddin gibi taşır yükü, \\ Yatar Bursa kalesinde. \\ Yüreği delinip batmadan, \\ şarkısı tükenip bitmeden, \\ cennetini kaybetmeden, \\ yatar Bursa kalesinde. (Nâzım Hikmet, 2009)
}

Bourdieu sosyolojisi çerçevesinde değerlendirildiğinde, Nâzım Hikmet, aktörlerinden biri olduğu yazınsal alanda hem şair habitusu hem de ona bağlı oluşan çok yönlü birikimi, beğenileri, algısı, kültürel sermayesi, toplumsal sermayesi ve bu sermayelerin dönüştüğü simgesel sermayesiyle çok önemli bir konumdadır. Habitusalan-sermaye ilişkiselliği, Nâzım'ın hem yazınsal yaşamında hem de kişisel yaşantısında belirleyici durumdadır. Nâzım Hikmet, eğitimi, ailesi, ilişkileri, yani tüm yaşamı doğrultusunda oluşan ve sürekli dönüşen, yeniden yapılanan, habitusunun bir çevirisi olarak ele alınabilecek şiirinde, kişisel yaşamından çokça ipucu verir okura. Bu anlamda, yaşamı ve sanatı arasında belirgin bir bağ ve ilişkisellik söz konusudur. Enver Aysever, Tepeden Tırnağa İsyan Nâzım Hikmet başlıklı biyografi türündeki kitabında bu ilişkiselliği şöyle dile getirir: "[...] Dünyada çok az şairin yaşamı ve şiiri arasında bu türden bir koşutluk vardır. Nâzım, ne gördü, işitti, düşledi, düşündüyse şiirinde buluruz bunu" (2018, s. 171). Yaşamı ve şiirinin koşutluğunun en güzel örneklerinden biri ise 11 Eylül 
1961 tarihinde Doğu Berlin'de kaleme alınan "Otobiyografi”7 (Nâzım Hikmet, 2009) adlı şiiridir:

1902 'de doğdum

doğduğum şehre dönmedim bir daha

geriye dönmeyi sevmem

üç yaşımda Halep'te paşa torunluğu ettim

on dokuzumda Moskova'da komünist Üniversite öğrenciliği

kırk dokuzumda yine Moskova'da Tseka-Parti konukluğu

ve on dördümden beri şairlik ederim

$[\ldots]$

Nâzım Hikmet'in yaşamının kendi ağzından anlatılmış etkileyici ve şiirsel bir özeti gibi değerlendirilebilecek bu şiirde, şairin yaşamının kırılma noktaları, hapislikleri, özgürlükleri, kısıtlarla dolu dönemleri, bolluk günleri, ideolojisi, aşkları, hastalığı, hayatı yaşayış biçimi şairin kendisi tarafından okurunun gözleri önüne serilmiştir. Şair, yaşamındaki iniş çıkışları birkaç dizede özetler gibidir:

\section{[...]}

hapislerde de yattım büyük otellerde de

açlık çektim açlık gırevi de içinde ve tatmadığım yemek yok gibidir

otuzumda asılmamı istediler

kırk sekizimde Barış madalyasının bana verilmesini

verdiler de

otuz altımda yarım yılda geçtim dört metre kare betonu

elli dokuzumda on sekiz saatta uçtum Pırağ'dan Havana'ya

[...]

Şiirin en dikkat çeken bölümlerinden biri ise hiç kuşkusuz şairin kendi dilinde yasaklı olduğunu belirttiği şu dizelerdir:

$[\ldots]$

yazılarım otuz kırk dilde basılır

Türkiye'mde Türkçemle yasak

[...]

Türkçe şiirin sesini çeviriler yoluyla tüm dünyaya duyuran, en fazla dile çevrilen şairinin kendi döneminde memleketinde yasaklı olma durumu dikkat çekicidir. Onca yaşanmışlığa, çekilen acılara, keder içinde yıllarını geçirmiş olmasına karşın yaşamından memnun olduğunu belirten şair, o bildik umutlu tavrıyla okurun üzerinde olumlu bir etki bırakarak, "Yaşamak güzel şey be kardeşim" dercesine şiirini sonlandırır:

$[\ldots]$

sözün kısası yoldaşlar

bugün Berlin'de kederden gebermekte olsam da insanca yaşadım diyebilirim

ve daha ne kadar yaşarım

7 "Otobiyografi" adlı şiirin tamamı için bakınız: Ek 1 
başımdan neler geçer daha

kim bilir.

Nâzım Hikmet, tüm yaşamı ve yaşamının bir yeniden yazımı olan şiiri ile alanın en büyük değerlerinden biridir; ancak uzun hapishane döneminden başlayarak ölümüne dek, yaklaşık otuz yıl boyunca, ülkesinde yasaklı olan şairin alandaki dolaşımının eksikliği nedeniyle kendi döneminde Türkçe şiirdeki etkisinin sınırlı kaldığı düşünülebilir. Nâzım’ın yaşadığı dönemde eserlerinin Türkçede ne şekilde dolaşımda olduğu/olamadığı Ek 2'de yer alan Tablo 1'de gösterilmiştir. Nâzım Hikmet'in eserleri 1938-1951 yılları arasında ne yazık ki kendi dilinde ve kendi ülkesinde ideolojik gerekçelerle yayınlanamamıştır. Eserler, 1965 yılından itibaren ise özellikle Memet Fuat'ın büyük çabası, uzun çalışmaları ve annesi Piraye'nin, Nâzım'ın onda bulunan tüm şiirlerini özenle saklaması sayesinde derlenerek farklı kitaplar hâlinde önce De Yayınları bünyesinde yayınlanmaya başlamıştır: Piraye İ̧̧in Yazılmış Saat 21-22 Şiirleri (1965), Dört Hapishaneden (1966), Memleketimden insan Manzaraları (1966), Rubailer (1966) bunlardan bazılarıdır. Bu anlamda, bugün okurunun Nâzım'ın şiirlerini eksiksiz biçimde okuma şansı bulmasının, Nâzım'a duyduğu kızgınlığa ve yaşadığı kalp kırıklığına rağmen şiirleri saklayan Piraye sayesinde olduğu düşünülebilir. Öte yandan, 1960'larda Dost, Bilgi, Ararat, İzlem, Kovan Kitabevi gibi birçok yayınevinde Ülkü Tamer, Şerif Hulûsi, Besim Akımsar, Yaşar Uçar, Mehmet Ulusel gibi isimlerin derlemeleriyle Nâzım'ın çeşitli eserleri yayınlanmaya başlamıştır. 1970'lerde Cem Yayınevi tarafından Asım Bezirci ve Şerif Hulûsi'nin yayına hazırladığı eserler yayınlarken, 1981-2002 yılları arasında ise Adam Yayınları tarafından Nâzım'ın tüm eserleri farklı isimlerle yayınlanmıştır. 2002 yılından itibaren Yapı Kredi Yayınları da Nâzım Hikmet eserlerini yayınlamaya başlar ve 2010 yılı itibariyle de eserler yalnızca Yapı Kredi Yayınları bünyesinde Türkçe okurlarıyla buluşmaya devam etmektedir (bkz. Nâzım Hikmet Bibliyografyası) ${ }^{8}$. 1965 yılından sonra tüm eserleri düzenlenip yeniden ya da Türkçede ilk defa yayınlanarak dolaşıma giren Nâzım Hikmet şiirlerinin, 1960'lardan sonra ideolojisinin de etkisiyle toplumcu gerçekçiler tarafından sahiplenildiği söylenebilir. Böylece, Nâzım Hikmet'in şiiri yazıldığı dönemde değil, ölümünden sonra yoğunlukla okunmaya başlamıştır.

Günümüzde ise Nâzım Hikmet'in en çok okunan, hakkında akademik anlamda en çok araştırma ve inceleme yapılan, en çok alıntılanan ve çevrildiği çok çeşitli diller vasıtasıyla Türkçe şiirdeki uluslararası boyutta tanınırlığa ve dolayısıyla en geniş hedef kitleye erişmiş şair olduğunu söylemek pek de yanlış olmaz. Şiirsellik bağlamında ise okurunu hem biçim ve tema hem nicelik ve nitelik bakımından fazlasıyla doyurmuştur. Yaşadığı zorluklara ve kısıtlara rağmen, boyun eğmeden sanatına ve yaşama tutunan Nâzım Hikmet, simgesel sermayesinin gücüyle bugün de şiirdeki bu güçlü konumunu korumaktadır. Bourdieu'nün yazınsal alan bağlamında, güç ilişkileri ve elde edilen gücü muhafaza etmek için çabalama konusu üzerinde durduğu gibi Nâzım Hikmet de şiiri, ideolojisi, hayatı algılayış biçimi ve şair habitusu doğrultusunda yazınsal alanda aldığı konumu sayesinde, içinde bulunduğu çetin mücadele sonucunda gücünü muhafaza etmeyi başarmıştır; sonuçta ise politik alanda iktidarı elinde bulunduran, onu hapse

\footnotetext{
${ }^{8}$ http://nazimhikmetmerkezi.com/bibliyografya-tarama/\#tarama
} 
atmak için çabalayan, özgürlüğünü elinden alan ekonomik sermaye sahibi eyleyiciler değil, kültürel, toplumsal ve simgesel sermaye sahibi Nâzım Hikmet, uluslararası tanınırlığa ve kültürel üretim alanındaki değerli konuma ulaşmıştır.

\subsection{Dünyada Nâzım Hikmet İmgesi}

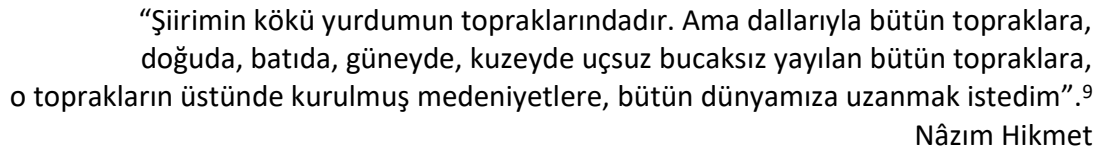

Nâzım Hikmet'in çok sesli, dinamik, yenilikçi şiiri yalnızca memleketinde duyulmaz; hem alandaki konumu, hem yaşadığı mahkûmiyet, hem ideolojisi, hem de şiirinin gücü sayesinde Nâzım'ın sesi onu tanıyan, davasında ona destek olan aydınların çabası ve yapılan çeviriler yoluyla dünyada da duyulur. "Anayurdundan ayrılmak zorunda kalan bu Türkiyeli ozan bütün dünya uluslarına Türk kültürünü, Türk sanatını tanıttı. Çin'den Küba'ya, Finlandiya'dan Tanganika'ya dek..." (Ataöv, 2019, ss. 106-107). Mutlu Konuk, Randy Blasing ile birlikte Nâzım Hikmet şiirlerini İngilizceye çevirip yayınladıkları Poems of Nâzim Hikmet (2002) adlı kitabın "Introduction" başlıklı bölümünde şiirleri elliden fazla dile çevrilen Nâzım'ı, 20. yüzyılın büyük uluslararası şairlerinden biri olarak tanımlar ve Nâzım'ı Whitman'a benzeterek, aynı anda kendisi, ülkesi ve dünya adına konuşabildiğinden söz eder.

Cevat Çapan, Işık Üniversitesi'nde gerçekleştirilen görüşmede ${ }^{10}$, Nâzım Hikmet'in hayat görüşünün ve şiirinin evrenselliğini vurgulayarak, farklı dillere yapılan seçme şiirlerinin çevirileri dışında, Nâzım'ın şiirlerinin eksiksiz şekilde ilk olarak Joyce Salvadori Lussu tarafından İtalyancaya çevrildiğinden söz etmiştir. Bu noktada, Lussu'nun ideolojik görüşünden, hayatı algılayış biçiminden söz etmek oldukça anlamlı olabilir. 8 Mayıs 1912'de Floransa'da doğan Lussu, faşizme karşı bir duruş sergileyen aktivist bir yazar ve çevirmendir. Lussu, sol görüşü benimsemesi, 'anti-faşist' bir organizasyon olan 1929-1945 yılları arasında Nazi'ye karşı faaliyet gösteren 'Giustizia e Libertà' hareketine üyeliği ve bu doğrultuda yaptığı çalışmalar ile bilinirr ${ }^{11}$ (bkz. Trenti, 2009). Lussu, Dünya Barış Hareketi çerçevesinde gittiği Stokholm'de Nâzım Hikmet ile tanışır ve şiirlerini çevirmeye başlar. Nâzım Hikmet, 1960'larda Lussu'nun çevirileriyle İtalya'da popüler hâle gelir (bkz. Berk Albachten, 2009). Nâzım Hikmet'in yanı sıra dönemin az bilinen pek çok şairinin şiirlerini İtalyancaya çeviren Lussu, kelimelerin dolaşımına izin vererek direnişin değerlerini de taşıdığına inandığını dile getirir (bkz. Berk Albachten, 2009). Yapılan görüşmede Çapan, Yunanca çevirilerde öne çıkan ismin Yannis Ritsos olduğunu dile getirmiştir. Ritsos da tıpkı Lussu gibi, Nâzım ile aynı ideolojiyi benimsemiştir, Yunancada bu ideoloji çerçevesinde şiirler kaleme alan şair, Nâzım'ın kendisi ve şiiriyle tanıştıktan sonra, şiirlerini Yunancaya kazandırır. Ritsos'un Nâzım için

\footnotetext{
${ }^{9}$ Gürsel, Nedim (2008). Dünya Şairi Nâzım Hikmet. İstanbul: Doğan Kitap, 21.

${ }^{10}$ Cevat Çapan ile kişisel iletişim, 5 Haziran 2017

${ }^{11}$ http://www.enciclopediadelledonne.it/biografie/joyce-salvadori-lussu/ [9 Ekim 2020]
} 
yazdığı ve Çapan'ın Türkçeye kazandırdığı şiirin adı da oldukça dikkat çekicidir: "Bir Ad Müzik ve Evrene Dönüşünce" ${ }^{12}$.

Uzun yıllar hapishaneye mahkûm edilen Nâzım Hikmet'in özgür kalması için başta annesi ressam Celile Hanım olmak üzere tüm dostları büyük bir çaba gösterir. Hapishanedeki son zamanlarında, serbest kalmak uğruna açlık grevine başlayan Nâzım Hikmet'e destek olmak için "Türkiye içinde ve dışında, Amerika'dan Fransa'ya, Mısır'a, Hindistan'a kadar dünyanın önde gelen aydınları koro hâlinde seslerini yükseltir[ler] [...]" (Karaveli, 2017, s. 259); bu kampanyalardan biri de 1949 yılında aralarında Pablo Picasso, Paul Robeson, Jean-Paul Sartre gibi aydınların da yer aldığı bir grup tarafından Paris'te yürütülür. Bu kampanyadan bir yıl sonra ise Nâzım Hikmet, Dünya Barış Ödülü ile taçlandırılır. Nâzım'ın sesi Bursa'daki hapishane odasından dünyaya ulaşmıştır, bu kampanya da bunun en önemli kanıtlarından biridir. Bourdieu'ye göre "evrenselleştirme en mükemmel meşrulaştırma stratejisi[dir]" (2005, s. 221). Nâzım Hikmet'in uluslararası edebiyat ve ideoloji alanındaki konumlanışı Bourdieu'nün bu tespitinin açık bir örneği sayılabilir. Kendi ülkesinde hapishanede uzun yıllar tutulan ve kitapları yasaklanan bir şair, ideolojisi, şiirinin gücü ve çeviriler yoluyla evrenselleşir ve ülkesinin aksine, dünyada meşrulaşır.

Nâzım Hikmet, 1951'de ülkesinden ayrıldıktan sonra Türkiye Cumhuriyeti vatandaşlığından çıkarılır. Dünya dillerindeki dolaşımının başlangıcı da aynı tarihlere rastlamaktadır. Ek 2'de yer alan Tablo 2'de Nâzım'ın hem tutukluluk hem sürgün döneminde, ölümüne kadarki süreçte hangi dillere, kimler tarafından çevrildiği ve hangi yayınevleri bünyesinde yayınlandığı gösterilmiştir. Bu tabloya göre, şiirleri Rusça, Fransızca, İtalyanca, İspanyolca, İngilizce, Almanca, Japonca, Slovenceye çevrilmiştir. Hem çevrildiği diller hem de çeviren kişiler dikkate alındığında bu dolaşımın asıl tematiğinin öncelikle ideoloji olduğu göze çarpar. Örneğin, Havana ve Moskova'da komünizm yükselirken, Nazi dönemi bitmiş ve Avrupa ülkeleri II. Dünya Savaşı'ndan çıkmışken ya da Japonya'da Hiroşima ve Nagasaki'ye atılan atom bombası trajedisinin etkileri yaşanırken Nâzım Hikmet şiirlerinin çevrilmesi ve okunması, ideolojik tematiğin göstergesi sayılabilir. Nâzım Hikmet, ölümünden sonra kendi ülkesinde hâlâ tam anlamıyla dolaşıma girmeden önce uluslararası alandaki dolaşımını sürdürür. Ülkesinde yeniden dolaşıma girdiği 1965 yılına kadar da Avrupa ülkelerindeki çeviri hareketi sürdürülmüştür (bkz. Ek 2, Tablo 3). Öte yandan, ölümünden sonra Nâzım Hikmet'in tüm eserlerinin Türkçede yeniden yayınlanmaya başlaması, uluslararası edebiyat alanındaki dolaşımına da olumlu etki etmiştir, çünkü daha önce bilinmeyen şiirlerin Türkçede düzenlenip yayınlanması diğer dillerdeki yayınların da çoğalması sonucunu doğurur.

Michael Cronin, "Downsizing the World: Translation and the politics of proximity" (2008) başlıklı makalesinde mikro-makro bakışı anlatır ve insanların küçük bir yörüngede yerel hayatlar yaşadıklarını belirterek bu mesafeleri aşmak için zaman-mekân gerekliliğini vurgular; yazın alanında da bu durum ancak çeviri yoluyla mümkün kılınabilir. Nâzım da fiziksel koşullarının yarattığı kısıtları çeviri yoluyla aşarak şiirini tüm dünyaya duyurmuştur; kültürel sermayesinin gücü onu kapalı mekânda bulunduğu süreçte başka alanlara taşımıştır. Bu noktada, Sapiro'nun “Normes de traduction et

\footnotetext{
${ }^{12}$ https://www.antoloji.com/bir-ad-muzik-ve-evrene-donusunce-siiri/
} 
contraintes sociales" (2008) [Çeviri Normları ve Toplumsal Kısıtlar] başlıklı çalışmasında belirttiği metnin sosyal konumu ve metni aktaranın sosyal konumunun değişkenliğine ve ilişkiselliğine değinmek gerekebilir. Sapiro, politikanın baskın olduğu yerlerde sembolik malların üretiminin ve dolaşımının etkilendiğini dile getirir; politik alan baskınsa, kültürel üretim alanında devlet düzeninin üstünlüğü söz konusudur. Böyle bir durumda, çeviri ideolojik bir araç olarak düşünülebilir ve çeviri eser de bir çeşit simgesel sermaye aktarımı sayılır. Nâzım Hikmet gibi ülkesinde yasaklı ve tutuklu bulunan bir entelektüelin eserlerinin çevirisi, Bourdieu'nün esere tüm toplumsal mekanizmalar gözetilerek gerçekleştirilecek bütüncül bakış açısı doğrultusunda değerlendirildiğinde, simgesel sermaye aktarımı olarak düşünülebilir. Nâzım Hikmet'in şiirlerinin çevirilerini yapanlar, ideolojik bir zeminde o çeviriyi gerçekleştirmeyi seçmiş olabilirler. Şairin ve çeviriyi yapanların ideolojik anlamdaki paralelliği ve ilişkiselliği de Nâzım Hikmet’in mesafeleri aşmasını ve şiirlerinin çeviri yoluyla dolaşımı ile sesini diğer dillerde duyurmasını sağlamıştır.

Cronin (2008), makalesinde şu cümleyi alıntılar: “[...] insanlar için mesafe fiziksel olmaktan çok, sosyaldir" (akt. Massey, 2004). Bu noktada Cronin, ulus ötesi/mekân ötesi bir bakıştan söz eder; öyleyse insanların fiziksel/mekânsal yakınlığı ya da uzaklığı onların sosyal anlamdaki ilişkiselliğini belirlemez. Nâzım Hikmet'in dünyada alımlanmasında da böyle bir ilişkisellik söz konusudur. Nâzım Hikmet'in hem şiirleri hem de ideolojisi, şairin içinde bulunduğu kapalı mekânın kısıtlarına karşın, makro bakış açısıyla değerlendirildiğinde, çeviriler ve ideolojik merkezli kampanyalar, çalışmalar yoluyla ulus ötesi bir dolaşıma uğramıştır; bu da Nâzım Hikmet'i uluslararası bir değer olarak karşımıza çıkarır.

Nâzım Hikmet'in uluslararası boyutta büyük ilgi görmesini, Bourdieu'nün sosyolojik bakış açısıyla değerlendirdiğimizde, uzam kavramına değinmek faydalı olabilir: "Uzam, birbirlerinin dışında yer alan, birbirlerine göre karşılıklı dışsallıklar ve iç içelik, yakınlık ya da uzaklık bağıntılarıyla olduğu kadar düzenleme bağıntılarıyla - üstünde, altında ve arasında gibi - tanımlanan, ayrı ve bir arada bulunan konumlardan oluşan bir bütündür" (Bourdieu, 2005, s. 18). Öte yandan, "uzamın kısıtlı bir yerinde bulunan insanlar hem (özellikleri ve yatkınlıkları, zevkleri nedeniyle) daha yakın olacak hem de yakınlaşmaya daha çok eğilim göstereceklerdir; bir araya gelmeleri, harekete geçmeleri de daha kolay olacaktır" (Bourdieu, 2005, s. 24). Bu açıklamalardan hareketle, Nâzım Hikmet - Picasso, Robeson, Sartre gibi sanatçıların aynı paralelde ve uzamsal bağlantı, ilişkisellik içinde hareket etmeleri Bourdieu'nün toplumsal uzama dair açıklamalarıyla düşünüldüğünde olağan bir sonuçtur. Uzamın kısıtlı bir yerinde bulunan bireyler, habitusları, yatkınlıkları, konumları doğrultusunda bir araya gelirler ve aynı ya da benzer amaçlar için birlikte harekete geçerler.

Nâzım Hikmet, 1950'de çıkarılan Genel Af Yasası'ndan yararlanarak "özgürlüğüne" kavuştuysa da kendi ülkesinde hâlâ yasaklıdır, üstelik serbest bırakılmış olsa da sürekli gözetim altındadır, maddî sıkıntılar ve zorluklar içinde ailesiyle bir yaşam sürmeye çalışmaktadır; ancak polis gözetimi altında olma durumunun üstüne bir de kalp rahatsızlığına ve yaşına rağmen askere çağrılması sebebiyle -Sabahattin Ali gibi 
öldürülme korkusundan dolayı- çok sevdiği memleketinden kaçmayı plânlar. 1951'de Refik Erduran ile yaptıkları planın iyi sonuçlanması neticesinde, memleketinden emaneten alınmış bir sürat motoru, sonra kabul edildiği ve içinde "Save Nâzım Hikmet" [“Nâzım Hikmet'i Kurtarın”] ilânının asılı olduğunu gördüğü bir Romanya şilebiyle gittiği Bükreş'ten sonra geçtiği Moskova'da törenle karşılanır. Şairin çokça karşılaştığı bu tezat yaklaşımlar, "Otobiyografi" şiirinde şair tarafından "otuzumda asılmamı istediler / kırk sekizimde Barış madalyasının bana verilmesini / verdiler de" dizeleriyle anlatılır. Bu durum, Nâzım'ın alanda aldığı konumunun ve simgesel sermayesinin bir sonucu olarak değerlendirilebilir. Nâzım Hikmet'in onlarca dile yapılan çevirilerle alanda etkin bir rol oynadığı düşünülebilir; her ne kadar ideolojisi sebebiyle kısıtlara maruz kalmış, iktidarın tahakkümü sonucunda özgürlüğünden mahrum bırakılmış olsa da tahakküme hiçbir şekilde boyun eğmemesi ve şiirlerini her koşulda yazmaya devam etmesi sayesinde çok önemli bir simge hâline gelmiştir. Bu anlamda, şiirinin öznesi olan Nâzım Hikmet, alandaki konumu sebebiyle bir nesneye dönüşmüş sayılabilir. Şairin simgesel sermayesinin de bugün hâlâ onunla aynı paralelde düşünen, yazan, araştırma yapan pek çok insana değer ve prestij kazandırdığı bir gerçektir.

Öyleyse, Nâzım'daki dünya insanı bakış açısının ve ideolojisinin ona uluslararası anlamda tanınma olanağı sunduğu söylenebilir; öte yandan, temalarının evrenselliği, çeşitliliği ve şair dehası da uluslararası alanda önemli bir yer bulmasında belirleyicidir. Döneminin popülerliğini ölümünden yıllar sonra dahi sürdürebilmesi de bunun bir sonucu sayılabilir. Sınırlı bir ön bakışla dahi, şair ve çevirmeni birleştiren tematiğin öncelikle ideolojik olduğu görülebilir. ${ }^{13}$ Tablo 1 ve Tablo 2 kıyaslandığında, Nâzım Hikmet hayattayken, eserlerinin yabancı dillerdeki yayınlarının, Türkçe yayınlardan nicelik bakımından fazla olduğu görülebilir, bu durum ülkesinde Nâzım’ın özgürlüğünün kısıtlanmasının bir sonucudur. Nâzım Hikmet'in dünyada oluşan imgesi, kültürel ve simgesel sermayesinin bir yansıması sayılabilir ve Sapiro'nun çeviri, kısıtlar, yazınsal metinlerin uluslararası dolaşımı üzerine yaptığı çalışmalarda belirttiği gibi Nâzım’ın alanda karşılaştığı kısıtlar onun uluslararası tanınırlığını bir anlamda tetiklemiştir. Nâzım, alanda kendisiyle aynı ideolojiye sahip olan, toplumsal uzamda birlikte hareket ettiği aktörlerin ilgisini çekmiştir. Nâzım'ın karşılaştığı politik, kültürel ve ekonomik kısıtlar, iktidar sahiplerinin tahakkümü ve simgesel şiddet sebebiyle memleketinde gerçekleştiremediği edebiyat alanındaki dolaşım, şairin ülkesi dışında hem çeviriler hem de kampanyalar sonucunda gerçekleştirilmiştir, böylece kısıtlar onun uluslararası alana taşınmasına katkıda bulunmuştur.

${ }^{13}$ Ayrıntılı inceleme doktora tez çalışmasında yapılacaktır. 


\title{
3.3. Nâzım Hikmet'in Kapalı Mekânda Kurduğu Usta-Çırak iliş̧kileri, Yaratıcılığı ve Üretkenliği
}

\author{
"Boş durmak yok! \\ Şiirler... Mektuplar... On binlerce dizelik destanlar... \\ Dokumacılık ve cezaevi bahçesinde şövale başına geçip yapılan resimler... \\ Yetenekli gençlere resim hocalığı". ${ }^{14}$
}

(Orhan Karaveli)

Nâzım Hikmet, ömrünün büyük bir kısmını geçirdiği hapishanelerde farklı kişilerle çeşitli ilişkiler kurar ve bu süreçte şairin okuma, üretme, yeniden yazma, öğretme ve bilgiyi paylaşma arzusu açıkça gözlemlenir. Uzun yıllar kapalı bir alanda özgürlüğü oldukça sınırlandırılmış bir insan olarak, içinde bulunduğu olumsuz, zorlayıcı ve yıpratıcı koşullara ve kısıtlara rağmen olumlu bir tutum sergileyen Nâzım Hikmet, sahip olduğu en belirgin özelliklerden biri olan yaşama sevincinden, umut dolu olma ve umudu yayma hâlinden hiç vazgeçmemiştir. Bu özelliği, hapishanenin zorlu koşullarında oluşturduğu iletişim şeklinden ve kurduğu usta-çırak ilişkilerinden açıkça gözlemlenebilir.

Nâzım Hikmet, parmaklıklar ardındaki günlerini önceleri Çankırı Hapishanesi'nde geçirmeye başlar, fakat kalbindeki rahatsızıı açısından karasal iklim şairi oldukça zorlar ve Kemâl Tahir, Nâzım'ın Bursa'ya geçiş yapabilmesi için elinden geleni yapar. Nâzım Hikmet'in Bursa Hapishanesi'ne geleceğini öğrenen mahkûmlar arasında heyecanlı bir bekleyiş başlar. Büyük bir merakla bekleyen mahkûmlardan biri de Raşit Kemâli'dir; sonrasında yazar Orhan Kemâl olacağından habersizdir. Raşit Kemâli, Nâzım'ın koğuş arkadaşı olmaya çok heveslidir ve istediği gibi de olur, artık onun için bir hazine olan büyük şair Nâzım Hikmet'le aynı havayı solumaktadır. Aralarında başlayan iletişim kısa sürede öğretmen-öğrenci ilişkisine evrilir ve Nâzım Hikmet önceleri şiir yazan Raşit Kemâli'yi düzyazıya yönlendirir. En sert eleştirmeni Nâzım Hikmet'tir ve bu durum onun edebiyat kariyerine büyük katkı sağlar; pek çok anlamda gelişen Raşit Kemâli, Türk edebiyatının en önemli yazarlarından biri olan Orhan Kemâl'e zaman içinde dönüşür. Nâzım Hikmet, küçük bir hapishane odasında oldukça kısıtlı imkânlar içinde olmalarına karşın, sanat, edebiyat, dil, felsefe, yazmak ve okumak üzerine bildiği, öğrendiği her şeyi aktarmaya başlar. Bu dersler, bugün edebiyatımızın en önemli yazarlarından birini adım adım yaratır. Yazma ve okuma işleri büyük bir hevesle sürer bu iki entelektüelin odasında; birbirlerinin hem arkadaşı hem yoldaşı hem de eleştirmeni olmuşlardır zamanla. Nâzım Hikmet, Bourdieu'nün habitusu tanımlarken belirttiği gibi yapılandırırken yapılanır, hem karşısındaki insanı geliştirir, öte yandan kendi de sürekli bir gelişim ve değişim hâlindedir. Habitus, "tarihin ürünü olduğundan, sürekli olarak yeni deneyimlerle karşı karşıya gelen ve durmaksızın onlardan etkilenen, açık bir yatkınlıklar sistemidir." (Bourdieu, Wacquant, 2012, s. 125) Öte yandan, "habitustan söz etmek, bireysel olanın, hatta kişisel, öznel olanın dahi toplumsal, kolektif olduğunu ortaya koymaktır. Habitus, toplumsallaşmış bir öznelliktir." (age., s. 116) Nâzım Hikmet de

${ }^{14}$ Karaveli, Orhan (2017). Tanıdığım Nâzım Hikmet. İstanbul: Kırmızı Kedi Yayınevi, 229. (Nâzım Hikmet'in hapishane bahçesinde şövale başında otururken, ayakta onu izleyen birkaç mahkûmla çekilmiş olan Nâzım Hikmet Vakfı Arşivi'nden alınmış bir fotoğrafının yanına yazılmış bir not.) 
bildiğini aktarması sayesinde bireysel bir yapılanma ve yapılandırmanın, toplumsal bir boyutu da olduğunu gözler önüne serer.

Nâzım'ın izlerini sanatında, kişiliğinde ve yaşamında açıkça gözlemleyebileceğimiz kişilerden biri de İbrahim Balaban'dır. Balaban için çocuk yaşta hapishaneye düşmesi ve orada Nâzım Hikmet gibi büyük bir şair, onun içinse bir öğretmen, bir usta ile tanışma fırsatı bulması yaşamının dönüm noktasıdır. Balaban ve Nâzım Hikmet arasındaki sıcak ilişki, Nâzım'ın Bursa Hapishanesi'ne nakli ile başlar. Balaban'ın Nâzım'ın kim olduğuna dair pek bir fikri yoktur, hapishanedeki insanlardan Nâzım'a dair duyduğu en belirgin şey, komünist olduğu ve o yüzden hapse düştüğüdür. Balaban, resim sanatına meraklı bir gençtir, fakat içinde bulunduğu çevrede sanata pek değer verilmemektedir. Nâzım'ın mahkûmların portrelerini yaptığını duyan Balaban soluğu şairin yanında alır ve Nâzım, ranzasında onun portresini yapmaya başlar, böylece Balaban, çocuksu bir heyecan ve hevesle kulak verdiği Nâzım Hikmet sayesinde resim yeteneğini keşfeder, resmin inceliklerini öğrenmeye başlar; örneğin, daha ilk dakikalarda kalemle nasıl ölçü alabileceğini öğrenir Nâzım’ı izlerken ve böylece Balaban, dört duvar arasında ilk resimlerini yapmaya başlar. Birlikte yedi yıl geçiren bu iki sanatçı arasında bir ağabey-kardeş, bir öğretmen-öğrenci, yani bir usta-çırak ilişkisi gelişir. Birlikte geçirdikleri yıllar boyunca, sanat, resim, felsefe, tarih gibi pek çok konuda Balaban'a öğretmenlik yapan şair, Balaban'ın tüm yaşantısını dönüştürür ve ona yol gösterir.

Balaban, birlikte geçirdikleri yedi yılı, kendi gelişimini ve Nâzım'ın o yıllarda neler yaşadığını kendi penceresinden, ayrıntılı bir biçimde, sıcak, samimi ve konuşur gibi bir üslûpla anlattığı Nâzım Hikmet'le Yedi Yıl (2003) adlı, günlük olarak nitelendirilebilecek kitabında Nâzım’la kurdukları ilişkinin başlangıcını şöyle dile getirir:

Yıl 1941, Şubat'ın 2'si. En güzel giysilerimi giydim; kahverengi üzerine ince çizgili... Ütülü gömlek ve kıravat. Saçlarımı iyice taradım. Ben, ikinci kısımda, Nâzım Hikmet birinci kısmın 53'ncü koğuşunda kalıyordu. Ve Bursa şehrine bakan koğuşa, Yusuf Usta ile beraber gittik. Benden başka hiçbir öğrenci, hiçbir okula böylesine girmemiştir. (Amacım ona portremi yaptırmak değil. Çırak durmaktı.). (s. 21)

Balaban böyle tanışır ustasıyla ve Nâzım, Balaban'ın portresini yapmaya koyulur. Balaban, portresi yapılırken, ustasının tüm hareketlerini gözlemler ve bir şeyler öğrenmeye çalışır: "Daha ilk günde, üç esaslı tekniği öğreniyordum: 'Hayali çizgi kareleri'ni, 'Yüzün astarını' ve de 'Işığın yansımasını'” (2003, s. 23). Öğrendiği kadarıyla ve yeteneği sayesinde resimler yapmaya başlayan Balaban, bir gün Nâzım'ın resmini yapmaya koyulur ve aralarındaki usta-çırak ilişkisi fiilen başlar. "Çıraklığa kabul edildiğim gün, o saat ve o anda utanmasam; 'Yaşasın tutsaklık!..' diye bağıracaktım. Dünyada benden başka hiçbir öğrenci, cezaevini mekân tutup da dünyanın en büyük şairi Nâzım Hikmet'i hoca olarak bulmamıştır" (s. 30) diyen Balaban, tutsaklığın yaşamına etkisine değinir ve ilk bakışta, kısıt ya da zorluk olarak görülecek şeylerin aslında insanın yaşamını olumlu anlamda dönüştürebilecek fırsatlar olabileceğini vurgular. Balaban, hapishanede edindiği toplumsal sermayesi yani kurduğu ilişkiler sayesinde kültürel sermayesini zenginleştirirken, Nâzım Hikmet'in simgesel sermeyesinden de yararlanır ve tüm 
bunların ilişkiselliği sonucunda yaşamını idame ettirebileceği ekonomik sermayesini resim ve sanat yoluyla elde eder.

Nâzım Hikmet ve Balaban'ın hapishane ortamında kurdukları bu ilişkiyi Bourdieu kavramlarıyla açıklamak için yukarıda (3.2. Dünyada Nâzım Hikmet İmgesi başlıklı bölümde) tanımına yer verilen uzam kavramı göz önünde bulundurulabilir. Bourdieu'ye göre, toplumsal uzamda bireyler sahip oldukları ekonomik ya da kültürel sermayeye göre konum alırlar ve uzamsal mesafe, toplumsal mesafeyle paraleldir. Nâzım Hikmet ve Balaban'ın toplumsal uzamın farklı alanlarında konumlanmış bireyler olmalarına karşın bir araya gelmelerini ise Bourdieu "kötü yerler" olarak tanımladığı yerlerin uzamsal mesafeyi değiştirmesiyle açıklar. Hapishane ortamında, yani "toplumsal sınırların çiğnenmesi" (Bourdieu, 2005, s. 24) ile fiziksel olarak normal koşullarda karşılaşamayacak bireyler bir araya gelebilirler. Bu noktada, Nâzım Hikmet'in köylü sınıfı ile hapishane ortamında karşılaşması, onları tanıması ve onlarla ortak hareket eder olması da bu bakış açısıyla açıklanabilir; Nâzım'ın hapishanede kooperatif kurması, dokuma tezgâhları oluşturarak hem kendi ailesi ve dostları için maddî olanak sağlaması hem de orada bulunan toplumsal uzamın alt tarafında konumlanan insanlara yardım etmesi, yol göstermesi bu anlamda Bourdieu'nün teorisini doğrular niteliktedir.

Nâzım Hikmet'in hapishane yıllarında, mektuplar yoluyla sürdürdüğü ilişkileri de hem şairin kendi yaşamı hem de karşısındaki insanlar açısından oldukça önemlidir; bunlardan biri Kemâl Tahir ile kurduğu ilişkidir. Kemâl Tahir, Nâzım Hikmet'in en değer verdiği, fikrine güvendiği, hem maddî hem manevî anlamda yardımını esirgemediği dostlarından biridir ve şair, bunu mektuplarında sıklıkla dile getirir. Çankırı Hapishanesi'nde beraberlerdir, fakat sonra farklı hapishanelere geçerler ve ilişkileri mektuplarla sürer. Nâzım Hikmet, hapishanedeki oda arkadaşı Orhan Kemâl'in bazı yönlerini ona benzettiğini ve Kemâl Tahir'e duyduğu özlemini böyle dindirmeye çalıştığını mektuplarında dile getirir (bkz. Tahir, 2017). Mektuplaşmalar sırasında Kemâl Tahir de Sinop Hapishanesi'ndedir, dolayısıyla mektuplar iki siyasî mahkûmun arasında bir köprüdür ve bu anlamda da oldukça önemlidir.

Nâzım Hikmet'in hapishane koşulları nedeniyle mektuplar yoluyla iletişimde olduğu en önemli isimlerden biri de Nâzım'ın öz oğlundan daha yakın olan oğlu, Memet Fuat'tır. Henüz dört yaşındayken annesi Piraye'nin Nâzım Hikmet ile evlenmesi, Memet Fuat'ın tüm yaşantısı, seçtiği meslek, yaşayış biçimi ve dünyaya bakış şekli üzerinde etkili olur. Nâzım Hikmet, Memet Fuat'ın iyi eğitim alması, iyi yetişmiş bir entelektüel olması için elinden geleni yapar ve bu durum şair hapishanedeyken dahi gönderdiği mektuplar aracılığıyla devam eder. Memet Fuat'ın derlediği Cezaevinden Memet Fuat'a Mektuplar (Şubat 2016) adlı kitabının da en başında yer alan, tarihsiz bir mektupta aralarındaki baba-oğul ilişkisinin yanı sıra usta-çırak ilişkisi de gözler önüne serilir:

Oğlum,

Mektubunu aldım. Bayram ettim. Sen daha o kadar gençsin ki hatıraları olmayan ve hatıralara değerlerini vermesini öğrenmemiş olansın. Halbuki ben artık hatıraları olan ve hatıralara değer verecek kadar ihtiyarlamışım. [...] Dünyada en çok sevdiğim insanlardan biri anandır ve senin sevgin hemen bunun yanındadır ve ondan ayrılmaz. [...] [A]ltı yıldan beri kafan ve yüreğin benden uzak büyüdü. 
Halbuki ben onları yaratıp yaratacağım en güzel eserler olarak ortaya çıkarak istiyordum. Ama her şeye rağmen sana güveniyorum, çünkü benden uzak, fakat yeryüzünün en akıllı ve en büyük kadınına yakın yaşadın. Beni adam eden, beni insan eden kadının tesiri yaratıcıdır [...]. Kitapları sevmene pek sevindim. Annen bana bir mektubunda şöyle yazmıştı:

'Kitaba düştüm, sabahtan akşama kadar kitap okuyorum.

Kitaplar akıllı

kitaplar büyük kitaplar aptal kitaplar çocuk, kitaplar en uzak, en güzel yolculuk...' Tabi annen bunu böyle kesik kesik yazmadı, daha taze, daha güzel yazdı ama ben onları körolası şair alışkanlığımla bu hale soktum. Kitapları kitap olarak okursan sade, hakikaten aptaldırlar, fakat onları hayatla ilgilendirerek okursan akıllı olurlar. Demek istediğim şu: kitapları sadece kitap oldukları için değil, hayatın bir parçası olarak oku ve hayatı doğru aksettirebildikleri derecede değerlendir. Kitapla hayatı birbirinden ayırma. Ve yalan söyleyen ümitsiz kitaplardan yalan söyleyen ümitsiz insanlardan kaçtığın gibi, hatta daha çok kaç ve ne öyle kitaplar, ne de öyle insanlarla konuş. [...]

Ama dur, ben şöyle düşüneyim ve gelecek mektubumda sana bir liste yazayım. Hatta bu listedeki kitapların bir kısmını tedarik edip sana yollayayım.

Gözlerinden öper ve hiç olmazsa ayda bir mektuplarını beklerim, sevgili oğlum. Baban. (Nâzım Hikmet, Şubat 2016, ss. 11-13)

Bu duygu dolu ve öğretici mektup, Nâzım ile Memet Fuat arasındaki sevgi bağını ve kültürel sermaye aktarımını açıkça gösterir. Memet Fuat'ın yazınsal alandaki konumu, yaşamı, dünyayı, insanları algılayış biçimi, kültürel sermayesi, toplumsal sermayesi ve simgesel sermayesi Nâzım Hikmet ile aralarında kurdukları baba-oğul bağı ile doğrudan ilişkilidir.

Bu mektuptan hareketle, Nâzım Hikmet'in hapishane yıllarında sevdiklerine sık sık ve düzenli olarak yazdığı mektupların üzerinde durmak faydalı olacaktır. O yıllarda içinde bulunduğu kapalı mekân ve karşılaştığı kısıtlar sebebiyle Nâzım ile sevdikleri arasındaki en önemli iletişim aracı mektuptur; hapishane koşullarından dolayı muhatabından önce hapishane görevlileri tarafından sakıncalı sayılabilecek cümleler olup olmadığının kontrol edilmesi amacıyla okunuyor olsalar da yazılan mektuplar sayesinde bugün okuru, Nâzım Hikmet'in ideolojisine, şiirine, felsefe, tarih ya da edebiyata dair fikirlerini daha iyi öğrenme, Nâzım’ın kişisel ve edebî gelişimine daha yakından bakma şansı bulmuştur. Öte yandan, Nâzım'ın bir eş, bir baba ya da bir dost olarak sahip olduğu toplumsal sermayesi, kişiliği, ilişkileri yani insanî yönü mektuplarla açıkça görünür kılınmıştır. Mektupların varlığı ise yine kısıtların bir sonucu sayılabilir, çünkü Nâzım Hikmet hapishanede olmasaydı fikirlerini yazarak ifade etmek durumunda kalmayacaktı ve "söz uçar, yazı kalır" misali, bu durumda bizler Nâzım'ın birtakım fikirlerini ya da şiirlerinin oluşma sürecini bu kadar yakından ve kendi cümleleriyle öğrenme şansı bulamayabilirdik. 
Hapishane yıllarında ilişki kurduğu insanlar dışında, Nâzım Hikmet'in sahip olduğu şeylerden biri bolca zamandır, bu sayede uzun saatlerini okumaya, yazmaya ve yeniden yazmaya ayırabilmiştir. Mediha Göbenli'nin “Nâzım Hikmet'in Estetik ve Politikası Üzerine Bir Deneme" adlı makalesinde belirttiği gibi: "Ne trajiktir ki hapishane Türkiye'nin yazarları ve aydınları için önemli bir 'okul' teşkil edecektir" (2018, para. 2). Nâzım için ve şairle yolları orada kesişen birçok insan için de bu böyle olmuştur. Nâzım Hikmet, hapishane odasında klasik eserleri yeniden okuma ve ayrıntılı biçimde inceleme şansı bulmuştur, bunun yansıması ise eserlerinde yeniden yazım olarak karşımıza çıkar. Örneğin, o yıllarda okuduğu Ferhat ile Şirin destanını, yapı-söküm tekniği ile geleneksel olanı, farklı biçimde, ideolojisi ve alanda aldığı konum doğrultusunda yeniden yazmıştır. Esra Dicle, Şiir Dünyadan ibaret Nâzım Hikmet Üzerine Yeni Çalışmalar adlı eserde yer alan “Kadınların Savaşı'nda Kadınların İsyanı'na Uzanan Çağrı: Barış” başlıklı makalesinde Nâzım Hikmet'teki yeniden yazma konusunu oyunları üzerinden ele almıştır: "Nâzım Hikmet'in oyun yazarlığında dikkat çeken özellik: yenidenyazım faaliyeti içeriyor olması!" (2019, s. 118) diyen Dicle'ye göre "'Lysistrata'daki anti-militarist söylem, 'Tartuffe'teki din merkezli ikiyüzlülük ve sahte sofuluk eleştirisi, anti-emperyalist, anti-militarist, sosyalist bir söylemin üretilmesi için yeterli-elverişli zeminler olarak görülür" (s. 150). Öte yandan Dicle, Nâzım'ın kısıtlı imkânlar içindeyken artan yaratıcılığını da şöyle vurgular:

[...] Nâzım Hikmet'in hapishanedeyken daha yoğun bir çalışma süreci ve oldukça yaratıcı bir dönemin içindeyken yazdığı, seçtiği alt metinlerle hem estetik hem ideolojik bir hesaplaşmaya giriştiği 'Yusuf ile Menofis ve Ferhad ile Şirin, Mehmene Banu ve Demirdağ Pınarının Suyu' oyunlarının, çok daha derinlikli, nitelikli oyunlar olduğunu söylemek mümkün. (s. 152)

Hapishanede üretkenliği ve yaratıcılığının arttığı düşüncesi bağlamında üzerinde durulması gereken eserlerden biri de Nâzım Hikmet'in külliyatının yapıtaşlarından biri olan ve 1939 yılında yazmaya başladığı Memleketimden insan Manzaraları'dır. Hapishane yıllarında yazılmaya başlanan bu eserde şair, Anadolu insanını tüm yönleriyle anlatır okuruna. Peki, Nâzım'ın hapishane öncesi dönemde kısıtlı bir iletişimle yüzeysel olarak ya da uzaktan uzağa soyut biçimde tanıdığını sandığı Anadolu insanı aslında kimdir? Bu sorunun cevabını Nâzım hapishane ortamında bulur. "Nâzım hapishanelerde toplumun bütün kesimlerinden insanlarla tanışıp, A. Kadir, Kemal Tahir, Orhan Kemal gibi siyasi mahkûmların dışında, Anadolu insanıyla buluşacaktır" (Göbenli, 2018). Aristokrat bir aileye mensup olan Nâzım, içinde büyüdüğü entelektüel alanda tanıdığı insanlarda gerçek Anadolu insanını pek de göremez, fakat hapishane yıllarında gerçek Anadolu insanını tanıma şansı bulduğunda şiirlerinde de bu yönde bir değişim yaşanır. Memleketimden insan Manzaraları adlı eserinde hapishanenin kısıtlı koşullarında tanıdığı Anadolu insanını okuruna tüm ayrıntılarıyla anlatır; kendini 'komünist şair' olarak tanımlayan biri için bu büyük bir fırsattır aslında. Haklarını savunduğu halkın gerçeğiyle yüzleşir, onları bu kez somut biçimde gözlemler ve onları çok yakından tanır. 
Nâzım Hikmet, Kemâl Tahir'e 20 Mart 1942 tarihinde Bursa Hapishanesi'nden gönderdiği mektupta Memleketimden insan Manzaraları'na dair plânını şöyle dile getirir:

1) İstiyorum ki okuyucu 12.000 mısraı bitirdikten sonra vıcık vıcık insan kaynaşan bir mahşerden geçmiş olsun. 2) İstiyorum ki insan mahşerinin konkre ifadesi okuyucuya ana hattında muayyen bir devirdeki, muhtelif sınıflara mensup Türkiye insanları vasıtasıyla Türkiye'nin muayyen bir tarihi devredeki sosyal durumunu anlatsın. Tabii donmuş bir halde değil, diyalektik seyri ve akışıyla. 3) İstiyorum ki, ikinci planda, Türkiye cemiyetini çevreleyen dünya durumu muayyen bir devrede- anlaşılsın. 4) İstiyorum ki -nerden gelinip, nerede olunduğunu, nereye gidildiği? sualine- sahanın içinde azami imkanlarla cevap verilsin. Bu dört nokta ana meselemdir. (Nâzım Hikmet, 2015, s. 148)

17.000 satırdan oluşan ve aslında 66.000 satırdan oluştuğu, Nâzım memleketinden kaçtığı zaman arkadaşlarına dağıtılan bazı bölümlerin bulunamadığı düşünülen bu eserin birinci bölümü 1941 yılında Haydarpaşa Garı'nda başlar ve tren hareket eder. Bu noktada, trende yazdığı "Saman Sarısı" (1961) şiirinde de göze çarpan, tren - Nâzım ilişkisine değinmek gerekirse: “[...] 'Memleketimden İnsan Manzaraları'nı yazdığı sırada Nâzım Hikmet hapistedir ve eserindeki trenlerin aksine, kıpırdayacak hiçbir yeri yoktur. Bu anlamda tren onun için bir hapis arkadaşı, gidemediği, gitmesine izin verilmeyen, onu tutsak eden mekânın, zamanın ya da yasanın panzehiridir de denebilir" (Irmak, 2019, ss. 47-48).

Şairin, hapishane koşullarında yaşadığı değişim şiirine de yansır. İlk dönem şiirlerindeki gür sesli, marş gibi olduğu düşünülen şiir anlayışı yerini daha farklı bir söyleyişe ve çok yönlü bir şiir anlayışına bırakır. "Hapishane ve sansür dolayısıyla ayrıca Nâzım Hikmet şiirlerini artık sesli okunacak biçimde değil de mırıldanır şekilde yazıp, 'bir çeşit yeni realizm'” (Babayev, 1982, s. 95) görüşüne ulaşacaktır. Şairin kendi sözleriyle: "Bunları, o günkü memleket şartlarında bir çeşit dumanla örtmek zorundaydım, ancak böylelikle bunları bastırabilirdi. Öte yandan bunlardan bazen Türkiye'nin realitesi bahis konusuydu” (s. 97). Zekeriya Sertel'in 'Mavi Gözlü Dev' isimli kitabında da tespit ettiği gibi, 'artık eskisi gibi uzun sokak nutukları yazmıyor. Bağıra bağıra propaganda yapmıyor. Gene devrimcidir, davasından ve kavgasından bir santim bile geride değildir. Ama, artık şiirlerinde yeni bir ton, yeni bir hava vardır.' (s. 317) (akt. Göbenli, 2018).

Öyleyse, Nâzım Hikmet hem maruz kaldığı kısıtlar sonucunda tanıma şansı bulduğu insanları hem de öncesinde ilişkide olduğu insanları kapalı mekânda dahi olsa bilgisi ile yapılandırırken, kendisi de vaktini bolca okuyarak geçirmesi sayesinde ve bir şekilde iletişimde olduğu insanlardan öğrendikleri ile yapılanır, kültürel sermayesini geliştirir ve bunu da şiirinde yeniden yazar. Tüm bu değerlendirmeler ışığında, Nâzım Hikmet'in kısıtlara karşın ve kısıtlar sayesinde hem kişisel anlamda hem edebiyat bağlamında geliştiği sonucuna varılabilir.

\section{Sonuç ve Değerlendirme}

$\mathrm{Bu}$ çalışmada, Bourdieu sosyolojisinin alan, habitus, ekonomik sermaye, kültürel sermaye, toplumsal sermaye, simgesel sermaye, çıkar, iktidar, tahakküm, boyun eğme, 
simgesel şiddet gibi kavramlarından yola çıkılarak, Sapiro'nun çeviri sosyolojisi bağlamında üzerinde durduğu ve politik, ekonomik, kültürel ve sosyal faktörler olarak değerlendirdiği kısıt kavramı çerçevesinde, Nâzım Hikmet'in uzun yıllarını geçirdiği hapishane koşulları ve kültürel üretim alanında maruz kaldığı kısıtların yaşamındaki ve eserlerinin dolaşımındaki olumlu sonuçları üzerinde durulmuştur. Bu bağlamda, Nâzım Hikmet'in içinde bulunduğu mücadeleli edebiyat alanında aldığı konum ve bu konumlanma sonucunda kurulan doğrudan ya da dolaylı ilişkilerin onun kişisel yaşamına ve yazın hayatına nasıl katkı sağladığı incelenmiştir.

Kemâl Tahir, eşine yazdığı bir mektupta Nâzım Hikmet'in 1948'de yazdığı "Öküzlerimin boynuzlarında aydınlanırken ortalık" dizesiyle başlayıp "ben sana âşık olmakla meşgulüm..." dizesiyle son bulan aşk temalı şiirini aktarır ve şairin kişiliğine dair önemli bir noktadan şöyle bahseder: "Nasıl hâlâ delikanlıdır şu Nâzım? Nasıl hâlâ on dokuz yaşındadır. Herifi hiçbir şey umutsuzluğa düşürmez, yıldırmaz, insanları ve sevgilisini sevmekten alıkoymaz. Nâzım dâhi şair kudreti kadar bu sevme kabiliyeti ile de dehşetli adamdır" (Tahir, 2017, 32). Kemâl Tahir'in de mektubunda bahsettiği gibi, Nâzım Hikmet hiçbir koşulda içinde yaşattığı umudunu ve insan sevgisini yitirmez, sürekli canlı tuttuğu umudu ve sevgiyi bir biçimde gerek davranışları ile çevresindeki insanlara gerek şiirleri, oyunları yoluyla okuruna aktarmayı da ihmâl etmez. Nâzım'ın bu olumlu tutumu onun üretkenliğinin ve yaratıcılığının hiçbir koşulda eksilmemesini sağlar.

Şiirinin öznesi konumunda olan Nâzım Hikmet, bugün alanda bir nesne olarak değerlendirilebilir; çünkü bir şairden öte, üzerine düşünülen, konuşulan, tartışılan, çeşitli kuramsal yaklaşımlarla, farklı bakış açılarıyla bilimsel boyutta incelenen ve farklı biçimlerde yeniden yazılan bir nesne konumundadır. Nâzım Hikmet, şiirinde yansıttığı dünya görüşü, alanda aldığı konum, tutsaklığı, sürgün yılları, evrensel şiir dili, edebiyat anlayışı ve çok çeşitli temaları ile tüm dünyayı kucaklayan çok önemli bir değerdir. Carolyn Forché'un, Mutlu Konuk ve Randy Blasing'in Nâzım şiirlerinin İngilizce çevirilerinden derlenen Poems of Nazim Hikmet (Revised and Expanded) adlı kitabın ön sözünde Nâzım'ın dizelerinden alıntı yaparak belirttiği gibi, Adana'daki, Yunanistan dağlarındaki ya da Çin'deki işçilere katılmak için hücresinden uçup onların yanına gider: (2002, s. xi)

\footnotetext{
Olamadığım yerlerde olabilmenin hasreti midir bende bu keder bu güneşli kış günlerinde: meselâ, İstanbul'umda köprünün üzerinde meselâ Adana'da arasında ırgatların, meselâ, Yunan dağlarında, meselâ Çin'de, meselâ, beni artık sevmeyenin başucunda. [...] (1949)
}

Nâzım şiir yoluyla zihninde birçok yolculuğa çıkar ve okurunu da beraberinde götürür, okurun ülkesinin neresi olduğu ya da onu hangi dilde okuduğu bu noktada önemli değildir, o da Nâzım ile birlikte çıkar yolculuklara. 
Bu makalede, sonuç olarak, kültürel bir ürünün dolaşıma girdiğinde bazı kısıtlarla karşı karşıya kaldığı deneyimlenmiştir. Bu kısıtlar alandaki eyleyicilerin çatışmaları, aldıkları konumlar ve görüş farklılıkları sonucunda ortaya çıkmıştır; politik, ekonomik, kültürel ve sosyal unsurlara bağlı olarak oluşan kısıtlar olumlu ya da olumsuz olmak üzere çeşitli sonuçlar doğurmuştur; aracıların kazanımları da dolaşımda ve alımlanmada etkili olmuştur. Bu anlamda ürünün alımlanması, oluşan koşullara bağlı olarak değişkenlik göstererek, okurun habitusunun tek başına belirleyici olmadığı ve fiziksel koşulların, ürüne ulaşabilme özgürlüğünün, kısıtların ve dolaşımın da ürünün alımlanmasında önemli rol oynadığı belirlenmiştir. Nâzım Hikmet'in eserlerinin, döneminde yasaklı olması ve dolaşımda bulunmaması, kendi ülkesindeki okuru ile gecikmeli şekilde buluşmasına neden olmakla birlikte, şairin uluslararası alanda dikkat çekmesini sağlamıştır, ideolojik anlamda aynı görüşü paylaşan kesim tarafından simgeleştirilmiştir ve şiirlerinin bu doğrultuda birçok dile çevrilmesi tanınırlığına katkıda bulunmuştur; öte yandan kısıtlı koşullarda kapalı mekânda bulunması şairin entelektüel gelişimini ve buna bağlı olarak yaratıcılığını olumlu yönde etkilemiştir. Bugün Nâzım Hikmet, yalnızca Türkçe şiirin değil, çeviri yoluyla dolaşıma girdiği dünya şiiri açısından düşünüldüğünde de edebiyat alanının en büyük ve en değerli şairlerinden biridir.

\section{Kaynakça}

Akyıldız, O. \& Gülsoy, M. (Yay. Haz.). (2019). Şiir dünyadan ibaret, Nâzım Hikmet üzerine yeni çalışmalar. İstanbul: Boğaziçi Üniversitesi Yayınevi.

Ataöv, T. (2019). Nâzım'ın hasreti. İstanbul: ileri Yayınları.

Babayev, E. (1982). Nâzım Hikmet'in sanatı. Türkenzentrum Berlin (Yay. Haz.). Berlin: Elefanten Press.

Balaban, ì. (2003). Nâzım Hikmet'le yedi yıl. İstanbul: Berfin Yayınları.

Berk Albachten, Ö. (2009). Dil sınırlarını aşan bir çeviri ortaklığı: Joyce Lussu ve Nâzım Hikmet, C.N. Çeviri Edebiyatı, 7, 140-145.

Berk Albachten, Ö. (2012). Turkish literature in Italian: 1923-2012, Istanbul Üniversitesi Çeviribilim Dergisi, 5, 89-120.

Bogenç Demirel, E. (2014). Çevirinin Bourdieu sosyolojisiyle yapılan yüzü, çeviri sosyolojisi, Cogito, 76, İstanbul: Yapı Kredi Yayınları, 402-416.

Boğaziçi Üniversitesi, Nâzım Hikmet Kültür ve Sanat Araştırma Merkezi. (2013). "Nâzım Hikmet Bibliyografyası”. M. İdiler, F. Ekingen, F. Mamondi ve Z. Günday (Yay. Haz.). Erişim adresi: http://nazimhikmetmerkezi.com/bibliyografya-tarama/\#tarama

Bourdieu, P. (2005). Pratik nedenler. (H. Uğur Tanrı̈ver, Çev.). İstanbul: Hil Yayın.

Bourdieu, P. \& Wacquant, L. (2012). Düşünümsel bir antropoloji için cevaplar. (N. Ökten, Çev.). İstanbul: Iletişim Yayınları.

Bourdieu, P. (2014). Seçilmiş metinler. (L. Ünsaldı, Çev.). Ankara: Heretik Yayınları. 
Cronin, M. (2008). "Downsizing the world: Translation and the politics of proximity", Benjamins translation library, 75, Beyond descriptive studies: Investigations in homage to Gideon Toury, A. Pym, M. Shlesinger, and D. Simeoni (Ed.), 265-276., doi:10.1075/btl.75.21cro

Dicle, E. (2019) Kadınların Savaşı'nda Kadınların İsyanı'na Uzanan Çağrı: Barış, Şiir Dünyadan ibaret, Nâzım Hikmet Üzerine Yeni Çalışmalar, İstanbul: Boğaziçi Üniversitesi Yayınevi, 116-154.

Forché, C. (2002). Foreword, Poems of Nazim Hikmet (Revised and Expanded). (R. Blasing ve M. Konuk Çev.), New York: Persea Books, Inc.

Göbenli, M. (9 Ocak 2018). Nâzım Hikmet'in estetik ve politikası üzerine bir deneme Erişim: $\quad$ https://www.insanokur.org/nazim-hikmetin-estetik-ve-politikasi-uzerinebir-deneme-doc-dr-mediha-gobenli/?amp [6 Şubat 2020]

Gürsel, N. (2008). Dünya şairi Nâzım Hikmet. İstanbul: Doğan Kitap.

Irmak, E. (2019). Majörler tükendi, minörlere yolculuk: 'Saman Sarısı'nda ses ve yol", Şiir Dünyadan ibaret, Nâzım Hikmet Üzerine Yeni Çalışmalar, İstanbul: Boğaziçi Üniversitesi Yayınevi, 39-58.

Karaveli, O. (2017). Tanıdığım Nâzım Hikmet. İstanbul: Kırmızı Kedi Yayınevi.

Massey, D. (2004). For space. London: Sage Publications Ltd.

Nâzım Hikmet. (2002). Poems of Nazim Hikmet (Revised and Expanded). (R. Blasing ve M. Konuk, Çev.). New York: Persea Books, Inc.

Nâzım Hikmet. (2009). Bütün şiirleri. İstanbul: Yapı Kredi Yayınları.

Nâzım Hikmet. (2011). Nâzım Hikmet'le söyleşi, Büyük insanlık "kendi sesinden şiirler". Bedri Rahmi Eyüboğlu (Kayıt). (A. Berktay, Çev.) İstanbul: Yapı Kredi Yayınları \& Türkiye İş Bankası Kültür Yayınları.

Nâzım Hikmet. (2015). Kemal Tahir'e mapushaneden mektuplar. İstanbul: İthaki Yayınları.

Nâzım Hikmet. (2016). Cezaevinden Memet Fuat'a mektuplar. İstanbul: Sözcükler Yayınları.

Nâzım Hikmet. (2017). Henüz vakit varken gülüm. İstanbul: Yapı Kredi Yayınları.

Paker, S. \& Yılmaz, M. (2004). A chronological bibliography of Turkish literature in English translation: 1949-2004, Translation Review, 68(1), 15-18. doi:10.1080/07374836.2004.10523860

Sapiro, G. (2008). Normes de traduction et contraintes sociales, Benjamins Translation Library, 75, Beyond Descriptive Studies: Investigations in homage to Gideon Toury, A. Pym, M. Shlesinger ve D. Simeoni (Ed.), 199-208., doi:10.1075/btl.75.16sap

Sapiro, G. (2016). How do literary works cross borders (or Not)? A sociological approach to 
world literature. Journal of World Literature, 1, 81-96. doi:10.1163/24056480$\underline{00101009}$

Simeoni, D. (1998). The pivotal status of the translator's habitus. Target, International Journal of Translation Studies. 10 (1): 1-39. doi:10.1075/target.10.1.02sim

Tahir, K. (2017). Kemal'den Piraye'ye mektuplar. Y. Bilge (Der.), H. Durgut (Yay. Haz.), İstanbul: Ithaki Yayınları.

Trenti, F. (2009). Il Novocento di Joyce Salvadori Lussu. Vita e opera di una donna antifascista. Sasso Marconi: Le voci della Luna Poesia.

Yavuz, H. (2005). "Nâzım: aşma ve avangard", Edebiyat ve sanat üzerine yazılar, İstanbul: Yapı Kredi Yayınları.

\section{Ek 1}

11 Eylül 1961 tarihinde Doğu Berlin'de kaleme alınan “Otobiyografi” adlı şiir:

"1902'de doğdum

doğduğum şehre dönmedim bir daha

geriye dönmeyi sevmem

üç yaşımda Halep'te paşa torunluğu ettim

on dokuzumda Moskova'da komünist Üniversite öğrenciliği

kırk dokuzumda yine Moskova'da Tseka-Parti konukluğu

ve on dördümden beri şairlik ederim

kimi insan otların kimi insan balıkların çeşidini bilir

ben ayrılıkların

kimi insan ezbere sayar yıldızların adını

ben hasretlerin

hapislerde de yattım büyük otellerde de

açıı çektim açıık gırevi de içinde ve tatmadığım yemek yok gibidir

otuzumda asılmamı istediler

kırk sekizimde Barış madalyasının bana verilmesini

verdiler de

otuz altımda yarım yılda geçtim dört metre kare betonu

elli dokuzumda on sekiz saatta uçtum Pırağ'dan Havana'ya

Lenin'i görmedim nöbet tuttum tabutunun başında 924'de

961'de ziyaret ettiğim anıtkabri kitaplarıdır

partimden koparmağa yeltendiler beni

sökmedi

yıkılan putların altında da ezilmedim 
951'de bir denizde genç bir arkadaşla yürüdüm üstüne ölümün 52 'de çatlak bir yürekle dört ay sırtüstü bekledim ölümü

sevdiğim kadınları deli gibi kıskandım şu kadarcık haset etmedim Şarlo'ya bile aldattım kadınlarımı konuşmadım arkasından dostlarımın

içtim ama akşamcı olmadım

hep alnımın teriyle çıkardım ekmek paramı ne mutlu bana

başkasının hesabına utandım yalan söyledim

yalan söyledim başkasını üzmemek için ama durup dururken de yalan söyledim

bindim tirene uçağa otomobile çoğunluk binemiyor operaya gittim çoğunluk gidemiyor adını bile duymamış operanın çoğunluğun gittiği kimi yerlere de ben gitmedim 21 'den beri camiye kiliseye tapınağa havraya büyücüye ama kahve falıma baktırdı̆ım oldu

yazılarım otuz kırk dilde basılır Türkiye'mde Türkçemle yasak

kansere yakalanmadım daha yakalanmam da şart değil başbakan filân olacağım yok meraklısı da değilim bu işin bir de harbe girmedim sığınaklara da inmedim gece yarıları yollara da düşmedim pike yapan uçakların altında ama sevdalandım altmışıma yakın sözün kısası yoldaşlar bugün Berlin'de kederden gebermekte olsam da insanca yaşadım diyebilirim

ve daha ne kadar yaşarım başımdan neler geçer daha kim bilir." 


\section{Ek 2}

Bu bölümde yer alan tablolar Boğaziçi Üniversitesi Nâzım Hikmet Kültür ve Sanat Araştırma Merkezi bünyesinde Boğaziçi Üniversitesi Kütüphanesi çalışanlarından Meryem İdiler, Filiz Ekingen Flores Mamondi ve Zeliha Günday tarafından 2013 yılında hazırlanan ve merkez tarafından her yıl güncellenen bibliyografyadan ${ }^{15}$ bazı bölümler, tarihsel dönemlere göre ayrıştırılıp bazı eklemeler ${ }^{16}$ yapılarak alınmıştır.

Tablo 1: 1928-1963: Nâzım Hikmet'in Hayattayken Türkçe Yayınlanmış Eserleri

\begin{tabular}{|c|c|c|c|}
\hline YII & Eser Adı & Yayınevi & Basım Yeri \\
\hline 1928 & Güneşi İçenlerin Türküsü & - & Bakü \\
\hline 1929 & 835 Satır & Ahmet Halit Kitaphanesi & istanbul \\
\hline 1929 & Jokond ile Si-ya-u & Akşam Matbaası & i̇stanbul \\
\hline 1930 & $1+1=1$ & Ahmet Halit Kitaphanesi & i̇stanbul \\
\hline 1930 & Varan 3 & Ahmet Halit Kitaphanesi & i̇stanbul \\
\hline 1931 & Sesini Kaybeden Şehir [şiir] & Remzi Kitaphanesi & ístanbul \\
\hline 1932 & Benerci Kendini Niçin Öldürdü? & Suhulet Kütüphanesi & i̇stanbul \\
\hline 1932 & $\begin{array}{l}\text { Bir Ölü Evi ya da Merhumun Hanesi, } \\
\text { Gülünçlü Komedya }\end{array}$ & Ahmet Halit Kitaphanesi & isstanbul \\
\hline 1932 & Gece Gelen Telgraf & Ahmet Halit Kitaphanesi & istanbul \\
\hline 1932 & Kafatası: Oyun, facia 3 kısım 15 bap & Suhulet Kütüphanesi & i̇stanbul \\
\hline 1932 & Orman Cücelerinin Sergüzeşti & Suhulet Kütüphanesi & İstanbul \\
\hline 1934 & Unutulan Adam & Resimli Ay Matbaası & İstanbul \\
\hline 1935 & Portreler & Şirket-i Mürettibiye Matbaası & i̇stanbul \\
\hline 1935 & Taranta Babu'ya Mektuplar & Yeni Kitapçı & i̇stanbul \\
\hline 1936 & Alman Faşizmi ve Irkçılığı & Kader Basımevi & i̇stanbul \\
\hline 1936 & it Ürür Kervan Yürür & Selamet Matbaası & ístanbul \\
\hline 1936 & Milli Gurur & Kader Matbaası & istanbul \\
\hline 1936 & $\begin{array}{l}\text { Simavne Kadısı Oğlu Şeyh Bedrettin } \\
\text { Destanı }\end{array}$ & 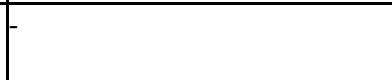 & istanbul \\
\hline 1936 & Sovyet Demokrasisi & Selamet Matbaası & istanbul \\
\hline 1937 & Kurtuluş Savaşı Destanı & Numune Matbaası & i̇stanbul \\
\hline 1938 & Yeşil Elmalar & Yenlap Yay. & istanbul \\
\hline 1951 & Seçilmiş Şiirler & Bulgaristan Komünist Partisi & Sofya \\
\hline 1954 & Bir Aşk Masalı & - & Sofya \\
\hline 1957 & Enayi & Dost Yay. & Ankara \\
\hline
\end{tabular}

\footnotetext{
${ }^{15}$ Bibliyografyanın tamamı için bkz: http://nazimhikmetmerkezi.com/bibliyografya-tarama/\#tarama
}

${ }^{16}$ Tablo 2 ve Tablo 3'te 'Dil' sütununda bulunan boşluklar doldurulmuştur. 
Nâzım Hikmet'in Edebiyat Alanındaki Konumuna ve Eserlerinin Çeviri Yoluyla

Dolaşımına Kısıtların Olumlu Etkileri

Tablo 2: 1950-1963: Nâzım Hikmet'in Yabancı Dillerde Ölümünden Önce Yayınlanmış Eserleri

\begin{tabular}{|c|c|c|c|c|c|}
\hline Yıl & Dil & Çeviren & $\begin{array}{l}\text { Çeviri Eser } \\
\text { Adı }\end{array}$ & Basım Yeri & Yayınevi \\
\hline 1950 & Rusça & A. Palladin & Stichi & Moskova & Chudoz. Liter \\
\hline 1951 & Fransızca & $\begin{array}{l}\text { Tristan } \\
\text { Tzara } \\
\text { (Hasan } \\
\text { Güreh'in } \\
\text { Notlarıly) }\end{array}$ & $\begin{array}{l}\text { Poèmes de } \\
\text { Nâzım } \\
\text { Hikmet }\end{array}$ & Paris & Éditeurs Français Réunis \\
\hline 1951 & Rusça & A. Babaeva & Izbrannoe & Moskova & Inostrannoi Literatura \\
\hline 1952 & Fransızca & $\begin{array}{l}\text { Chen Wei } \\
\text { ming }\end{array}$ & $\begin{array}{l}\text { Xi ke mei te } \\
\text { shi ji }\end{array}$ & Pekin & Ren min wen xue chu ban she \\
\hline 1952 & Fransızca & $\begin{array}{l}\text { Ahmet } \\
\text { Sadeq }\end{array}$ & $\begin{array}{l}\text { Manzümah } \\
\text { a'i az Nâzım } \\
\text { Hikmat }\end{array}$ & Tahran & $\begin{array}{l}\text { Muassasah-i matbu'ati-i Hunar } \\
\text { Pishraw }\end{array}$ \\
\hline 1952 & İngilizce & - & $\begin{array}{l}\text { Selected } \\
\text { Poems }\end{array}$ & - & Asoke Ghosh, Calcutta \\
\hline 1952 & Rusça & $\begin{array}{l}\text { A. Babaeva, } \\
\text { Radi Fish }\end{array}$ & $\begin{array}{l}\text { Rasskaz o } \\
\text { Turtsii } \\
\text { p'esa v } \\
\text { trekh } \\
\text { deistviiakh }\end{array}$ & Moskova & Inostrannoi Literatura \\
\hline 1953 & Fransızca & Wu meng & $\begin{array}{l}\text { Tu er qi de } \\
\text { hu shi }\end{array}$ & Şanghay & Ping Ming chu ban she \\
\hline 1953 & İspanyolca & $\begin{array}{l}\text { Francesa } \\
\text { por } \\
\text { AmaroVill, } \\
\text { Nueva y } \\
\text { Julio H. } \\
\text { Meirama }\end{array}$ & Poemas & $\begin{array}{l}\text { Buenos } \\
\text { Aires }\end{array}$ & Lautaro \\
\hline 1953 & Rusça & A. Babaeva & Izbrannoe & Moskova & Inostrannoi Literatura \\
\hline 1954 & İngilizce & Ali Yunus & Poems & New York & Masses\&Mainstream Inc. \\
\hline 1954 & Rusça & - & P'esy & Moskova & $\begin{array}{l}\text { Gosudarstvennoe Idatel'stvo } \\
\text { Iskusstvo }\end{array}$ \\
\hline 1955 & Fransızca & $\begin{array}{l}\text { Chen } \\
\text { Yansheng, } \\
\text { Wu } \\
\text { Chunqiu he } \\
\text { yi }\end{array}$ & $\begin{array}{l}\text { Ai qing de } \\
\text { chuan shuo }\end{array}$ & Şanghay & Ping Ming chu ban she \\
\hline
\end{tabular}




\begin{tabular}{|c|c|c|c|c|c|}
\hline 1955 & Fransızca & $\begin{array}{l}\text { Wei huang } \\
\text { nu }\end{array}$ & $\begin{array}{l}\text { Luo si tuo } \\
\text { fu cai fu }\end{array}$ & Pekin & Tong su du wu chu ban she \\
\hline 1955 & Japonca & $\begin{array}{l}\text { Horiuchi } \\
\text { Hiroko, } \\
\text { Murakami } \\
\text { Setsuko } \\
\text { Yaku }\end{array}$ & $\begin{array}{l}\text { Ai no } \\
\text { densetsu; } \\
\text { Tsuma e } \\
\text { gokuchu } \\
\text { yori }\end{array}$ & Tokyo & Wakosha \\
\hline 1955 & Rusça & A. Babaeva & $\begin{array}{l}\text { Chudak: } \\
\text { p'esa v } \\
\text { trekh } \\
\text { deistviakh s } \\
\text { prologom }\end{array}$ & Moskova & $\begin{array}{l}\text { Gosudarstvennoe Idatel'stvo } \\
\text { Iskusstvo }\end{array}$ \\
\hline 1955 & Rusça & - & Stikhi & Moskova & Pravda \\
\hline 1956 & Almanca & $\begin{array}{l}\text { Alfred } \\
\text { Kurella }\end{array}$ & $\begin{array}{l}\text { Hat es Iwan } \\
\text { Iwanowitsc } \\
\text { h } \\
\text { überhaupt } \\
\text { gegeben?: } \\
\text { Schauspiel } \\
\text { in drei } \\
\text { Akten und } \\
\text { fünf Bildern }\end{array}$ & Berlin & Henschelverlag \\
\hline 1956 & Almanca & $\begin{array}{l}\text { Alfred } \\
\text { Kurella }\end{array}$ & $\begin{array}{l}\text { Legende } \\
\text { Von der } \\
\text { liebe } \\
\text { Dramat. } \\
\text { Gedicht in } \\
3 \text { Akten u. } \\
5 \text { Bildern }\end{array}$ & Berlin & Henschelverlag \\
\hline 1956 & Almanca & - & $\begin{array}{l}\text { Türkische } \\
\text { Telegramm } \\
\text { e: Gedichte }\end{array}$ & Berlin & Volk und Welt \\
\hline 1956 & Japonca & $\begin{array}{l}\text { Mine } \\
\text { Toshio }\end{array}$ & $\begin{array}{l}\text { Gokuchu } \\
\text { Shokan: } \\
\text { Shishu }\end{array}$ & Tokyo & Kokubunsha \\
\hline 1956 & Japonca & $\begin{array}{l}\text { Mine } \\
\text { Toshio }\end{array}$ & $\begin{array}{l}\text { Shinda } \\
\text { shojo: } \\
\text { Shishu }\end{array}$ & Tokyo & Kokubunsha \\
\hline 1957 & Fransızca & Lei Nan & $\begin{array}{l}\text { Ta yong } \\
\text { yuan huo } \\
\text { zhe }\end{array}$ & Pekin & $\begin{array}{l}\text { Zong guo dian ying chu ban } \\
\text { she }\end{array}$ \\
\hline 1957 & Fransızca & $\begin{array}{l}\text { Charles } \\
\text { Dobzynski }\end{array}$ & $\begin{array}{l}\text { C'est un } \\
\text { der metier }\end{array}$ & Paris & Éditeurs Français Réunis \\
\hline
\end{tabular}


Nâzım Hikmet'in Edebiyat Alanındaki Konumuna ve Eserlerinin Çeviri Yoluyla

Dolaşımına Kısıtların Olumlu Etkileri

\begin{tabular}{|c|c|c|c|c|c|}
\hline & & & $\begin{array}{l}\text { que l'exil= } \\
\text { Gurbetlik } \\
\text { Zor Zanaat }\end{array}$ & & \\
\hline 1957 & İspanyolca & $\begin{array}{l}\text { Isidro } \\
\text { Flaumbau }\end{array}$ & $\begin{array}{l}\text { Existio } \\
\text { realmente } \\
\text { Ivan } \\
\text { Ivanovich?: } \\
\text { pieza en } \\
\text { tres actos y } \\
\text { nueve } \\
\text { cuadros }\end{array}$ & $\begin{array}{l}\text { Buenos } \\
\text { Aires }\end{array}$ & Editorial Adriana \\
\hline 1957 & İtalyanca & - & $\begin{array}{l}\text { Ma é poi } \\
\text { esistito } \\
\text { Ivan } \\
\text { Ivanovic? }\end{array}$ & Torino & Giulio Einaudi \\
\hline 1957 & Rusça & A. Babaeva & $\begin{array}{l}\text { Izbrannye } \\
\text { sochinenaii } \\
\text { a v dvukh } \\
\text { tomakh }\end{array}$ & Moskova & Khudozhestvennaia Literatura \\
\hline 1957 & Rusça & $\begin{array}{l}\text { Margarita } \\
\text { Aliger }\end{array}$ & $\begin{array}{l}\text { Stikhi i } \\
\text { poemy: } \\
\text { perevod s } \\
\text { turetskogo }\end{array}$ & Moskova & ITSK VLKSM Molodaia gvardiia \\
\hline 1958 & İtalyanca & $\begin{array}{l}\text { Franco de } \\
\text { Poli }\end{array}$ & Poesie & Milano & Edizioni Avanti \\
\hline 1958 & Japonca & $\begin{array}{l}\text { Mine } \\
\text { Toshio }\end{array}$ & $\begin{array}{l}\text { Shinda } \\
\text { shojo: } \\
\text { Shishu }\end{array}$ & Tokyo & Kokubunsha \\
\hline 1958 & Slovence & - & $\begin{array}{l}60 \\
\text { stihotvoren } \\
\text { ij }\end{array}$ & Moskova & Inostrannoi Literatura \\
\hline 1959 & Almanca & $\begin{array}{l}\text { Alfred } \\
\text { Kurella }\end{array}$ & $\begin{array}{l}\text { Ein } \\
\text { komischer } \\
\text { Mensch: } \\
\text { Schauspiel } \\
\text { in } 3 \text { Akten }\end{array}$ & Berlin & Henschelverlag \\
\hline 1959 & Almanca & - & Gedichte & Berlin & Volk und Welt \\
\hline 1959 & İspanyolca & $\begin{array}{l}\text { Alfredo } \\
\text { Varela }\end{array}$ & $\begin{array}{l}\text { Duro oficio } \\
\text { el exilio }\end{array}$ & Arjantin & Laurato \\
\hline 1960 & Almanca & $\begin{array}{l}\text { Alfred } \\
\text { Kurella }\end{array}$ & $\begin{array}{l}\text { Hat es Iwan } \\
\text { Iwanowitsc }\end{array}$ & Berlin & Henschelverlag \\
\hline
\end{tabular}




\begin{tabular}{|c|c|c|c|c|c|}
\hline & & & $\begin{array}{l}\text { h } \\
\text { überhaupt } \\
\text { gegeben?: } \\
\text { Schauspiel } \\
\text { in drei } \\
\text { Akten und } \\
\text { fünf Bildern }\end{array}$ & & \\
\hline 1960 & Almanca & $\begin{array}{l}\text { Alfred } \\
\text { Kurella }\end{array}$ & $\begin{array}{l}\text { Von allen } \\
\text { Vergessen: } \\
\text { Schauspiel } \\
\text { in sechs } \\
\text { Bildern }\end{array}$ & Berlin & Henschelverlag \\
\hline 1960 & İtalyanca & $\begin{array}{l}\text { Ignazio } \\
\text { Ambrogio }\end{array}$ & Poesie & Roma & Newton Compt. \\
\hline 1960 & Rusça & A. Babaeva & $\begin{array}{l}\text { Damoklov } \\
\text { mech: } \\
\text { dramatiche } \\
\text { skaia satira } \\
\text { v 2-kh } \\
\text { chastiakh }\end{array}$ & Moskova & MOTZK \\
\hline 1961 & Almanca & $\begin{array}{l}\text { Alfred } \\
\text { Kurella }\end{array}$ & $\begin{array}{l}\text { Josef in } \\
\text { Egyptenlan } \\
\text { d } \\
\text { Schauspiel } \\
\text { in } 3 \text { Akten } \\
\text { u. } 5 \text { Bildern }\end{array}$ & Berlin & Henschelverlag \\
\hline 1961 & Almanca & $\begin{array}{l}\text { Alfred } \\
\text { Kurella }\end{array}$ & $\begin{array}{l}\text { Legende } \\
\text { Von der } \\
\text { liebe }\end{array}$ & Leipzig & Reclam \\
\hline 1961 & Fransızca & $\begin{array}{l}\text { Charles } \\
\text { Dobzynski }\end{array}$ & $\begin{array}{l}\text { Paris, ma } \\
\text { rose... }\end{array}$ & Paris & Pierre Jean Oswald \\
\hline 1961 & İspanyolca & $\begin{array}{l}\text { Loenilde } \\
\text { Bernasconi }\end{array}$ & $\begin{array}{l}\text { La niel de la } \\
\text { esperanza y } \\
\text { otros } \\
\text { poemas: } \\
\text { precedidod } \\
\text { e un } \\
\text { mesaje a } \\
\text { los poetas }\end{array}$ & Havana & - \\
\hline 1961 & İspanyolca & - & $\begin{array}{l}\text { Poemas } \\
\text { desde la } \\
\text { carcel }\end{array}$ & Meksika & D.F: Munoz \\
\hline
\end{tabular}


Nâzım Hikmet'in Edebiyat Alanındaki Konumuna ve Eserlerinin Çeviri Yoluyla

Dolaşımına Kısıtların Olumlu Etkileri

\begin{tabular}{|c|c|c|c|c|c|}
\hline 1961 & İtalyanca & $\begin{array}{l}\text { Giancarlo } \\
\text { Vigorelli }\end{array}$ & $\begin{array}{l}\text { In } \\
\text { quest'anno } \\
1941 \\
\text { [poesie] }\end{array}$ & Milano & Lerici \\
\hline 1961 & İtalyanca & Joyce Lussu & $\begin{array}{l}\text { La conga } \\
\text { con Fidel }\end{array}$ & Milano & Ed. Avanti \\
\hline 1961 & Japonca & $\begin{array}{l}\text { Nakamoto } \\
\text { Nabuyuki } \\
\text { Yako, } \\
\text { Hattari } \\
\text { Shinroku }\end{array}$ & $\begin{array}{l}\text { Hikumetto } \\
\text { shishu }\end{array}$ & Tokyo & Lizukashoten \\
\hline 1961 & Rusça & M. Pavlovoj & $\begin{array}{l}\text { Novye } \\
\text { stichi }\end{array}$ & Moskova & Sovetskii Pisatel \\
\hline 1962 & Almanca & $\begin{array}{l}\text { Stephan } \\
\text { Hermlin }\end{array}$ & $\begin{array}{l}\text { Brief aus } \\
\text { İstanbul }\end{array}$ & Berlin & Deutsche Schallplatten Eterna \\
\hline 1962 & Almanca & $\begin{array}{l}\text { Alfred } \\
\text { Kurella }\end{array}$ & $\begin{array}{l}\text { Damoklessc } \\
\text { hwert }\end{array}$ & Berlin & Henschelverlag \\
\hline 1962 & Almanca & $\begin{array}{l}\text { Alfred } \\
\text { Kurella }\end{array}$ & $\begin{array}{l}\text { Ein } \\
\text { komischer } \\
\text { Mensch: } \\
\text { Schauspiel } \\
\text { in } 4 \text { Akten }\end{array}$ & Berlin & Henschelverlag \\
\hline 1962 & Almanca & $\begin{array}{l}\text { Alfred } \\
\text { Kurella }\end{array}$ & $\begin{array}{l}\text { Legende } \\
\text { Von der } \\
\text { liebe } \\
\text { Joseph in } \\
\text { Egyptenlan } \\
\text { d }\end{array}$ & Leipzig & Reclam \\
\hline 1962 & Fransızca & $\begin{array}{l}\text { Münevver } \\
\text { Andaç }\end{array}$ & $\begin{array}{l}\text { En Cette } \\
\text { Année Dix } \\
\text { Neuf Cent } \\
\text { Quarante } \\
\text { et Un: } \\
\text { Poème }\end{array}$ & Paris & F: Maspero \\
\hline 1962 & Rusça & - & $\begin{array}{l}\text { Biografices } \\
\text { kij Ukazatel }\end{array}$ & Moskova & Vsesojuznoj Kniznoj Palaty \\
\hline 1962 & Rusça & - & $\begin{array}{l}\text { Izbrannye } \\
\text { stikhi }\end{array}$ & Moskova & Khudozhestvennaia Literatura \\
\hline 1962 & Rusça & $\begin{array}{l}\text { Arif } \\
\text { Melikov }\end{array}$ & $\begin{array}{l}\text { Legenda o } \\
\text { Liubvi: } \\
\text { Balet v }\end{array}$ & Leningrad & Gos: muzykal'noe izd-vo \\
\hline
\end{tabular}




\begin{tabular}{|c|c|c|c|c|c|}
\hline & & & $\begin{array}{l}\text { Trekh } \\
\text { Aktakh }\end{array}$ & & \\
\hline 1962 & Rusça & - & $\begin{array}{l}\text { Vsemi } \\
\text { zabytyi, } \\
\text { Stanstsiia, } \\
\text { Korova, A } \\
\text { byl li Ivan } \\
\text { Ivanovich. } \\
\text { Dva } \\
\text { upriamstsa, } \\
\text { Damoklov } \\
\text { mech. }\end{array}$ & Moskova & $\begin{array}{l}\text { Gosudarstvennoe Idatel'stvo } \\
\text { Iskusstvo }\end{array}$ \\
\hline 1962 & Rusça & $\begin{array}{l}\text { L.N. } \\
\text { Starostova }\end{array}$ & $\begin{array}{l}\text { Vliublenno } \\
\text { e oblak: } \\
\text { skazki i } \\
\text { miniatiury }\end{array}$ & Moskova & Vostochnoi Literatura \\
\hline 1963 & Almanca & $\begin{array}{l}\text { H. Wilfred } \\
\text { Brands }\end{array}$ & $\begin{array}{l}\text { In Jenem } \\
\text { Jahr } 1941\end{array}$ & Berlin & Luchterhand \\
\hline 1963 & İtalyanca & Joyce Lussu & $\begin{array}{l}\text { Poesie } \\
\text { d'amore }\end{array}$ & Milano & Arnoldo Mondadori Editori \\
\hline 1963 & Rusça & - & $\begin{array}{l}\text { Moskovsko } \\
\text { e leto }\end{array}$ & Moskova & Pravda \\
\hline
\end{tabular}

Tablo 3: 1964-1965: Nâzım Hikmet'in Ölümünden Sonra Türkiye'de Dolaşıma Girmeden Önce Yabancı Dillerde Yayınlanmış Eserleri

\begin{tabular}{|l|l|l|l|l|l|}
\hline Yıl & Dil & Çeviren & Çeviri Eser Adı & $\begin{array}{l}\text { Basım } \\
\text { Yeri }\end{array}$ & $\begin{array}{l}\text { Yayıne } \\
\text { vi }\end{array}$ \\
\hline 1964 & Fransızca & $\begin{array}{l}\text { Philippe } \\
\text { Soupault }\end{array}$ & $\begin{array}{l}\text { Antholgie } \\
\text { poetique. }\end{array}$ & Paris & Éditeurs Français Réunis \\
\hline 1964 & Fransızca & $\begin{array}{l}\text { Münevver } \\
\text { Andaç }\end{array}$ & $\begin{array}{l}\text { Les Romantiques: } \\
\text { La vie est belle } \\
\text { mon vieux roman }\end{array}$ & Paris & Éditeurs Français Réunis \\
\hline 1964 & Fransızca & - & $\begin{array}{l}\text { Nâzım Hikmet: } \\
\text { Anthologie } \\
\text { poetique }\end{array}$ & Paris & Éditeurs Français Réunis \\
\hline 1964 & ispanyolca & - & $\begin{array}{l}\text { Leyenda de } \\
\text { amor: pieza en 3 } \\
\text { actos y cuadros }\end{array}$ & $\begin{array}{l}\text { Buenos } \\
\text { Aires }\end{array}$ & Editorial Adriana \\
\hline
\end{tabular}


Nâzım Hikmet'in Edebiyat Alanındaki Konumuna ve Eserlerinin Çeviri Yoluyla Dolaşımına Kısıtların Olumlu Etkileri

\begin{tabular}{|l|l|l|l|l|l|}
\hline 1964 & italyanca & $\begin{array}{l}\text { Giacomo } \\
\text { Manzoni }\end{array}$ & $\begin{array}{l}\text { Don Chisciotte: } \\
\text { per soprano, } \\
\text { piccolo coro e } \\
\text { orchestra da } \\
\text { camera }\end{array}$ & Milano & Edizioni Suvini Zerboni \\
\hline 1964 & Japonca & $\begin{array}{l}\text { Mine } \\
\text { Toshio }\end{array}$ & $\begin{array}{l}\text { Shinda shojo: } \\
\text { Shishu }\end{array}$ & Tokyo & Kokubunsha \\
\hline 1964 & Rusça & - & $\begin{array}{l}\text { Romantika: } \\
\text { Roman }\end{array}$ & Moskova & Sovetskii Pisatel \\
\hline 1964 & Rusça & - & $\begin{array}{l}\text { Sorok let: } \\
\text { izbrannye stikhi } \\
1921-1961\end{array}$ & Moskova & Khudozhestvennaia Literatura \\
\hline 1964 & Rusça & $\begin{array}{l}\text { L.N. } \\
\text { Starostova }\end{array}$ & $\begin{array}{l}\text { Vliublennoe } \\
\text { Oblak: Skazki i } \\
\text { Miniatiury }\end{array}$ & Moskova & Nauka \\
\hline 1965 & italyanca & $\begin{array}{l}\text { Joyce } \\
\text { Lussu }\end{array}$ & $\begin{array}{l}\text { Paesaggi Umani: } \\
\text { Memleketimden } \\
\text { Insan } \\
\text { Manzaraları }\end{array}$ & Milano & Lerici \\
\hline
\end{tabular}

